ABELLING IN SELF-SERVICE RETAIL: CAN THE PRESENTED FORM OF NUTRITIONAL INFORMATION ON PACKAGING INCREASE PERCEPTIONS OF HEALTHINESS AND PURCHASE INTENTION?

\author{
Bianca Castro da Silva Maraninchi Ricci \\ MA in Business Administration/Marketing from PPGAd/PUCRS, Porto Alegre, RS, Brasil. \\ bianca.ricci@acad.pucrs.br
}

\begin{abstract}
Vinícius Sittoni Brasil Ph.D in Business Administration/Marketing PPGA/UFRGS. Full Professor at Business School, Pontifical Catholic University of Rio Grande do Sul, Porto Alegre, RS, Brasil. vinicius@pucrs.br
\end{abstract}

Stefânia Ordovás de Almeida Ph.D in Business Administration/Marketing from FEA/USP. Professor at Graduate Program in Business Administration - PPGAd - Business School, Pontifical Catholic University of Rio Grande do Sul, Porto Alegre, RS, Brasil. stefania.almeida@pucrs.br

\begin{abstract}
\end{abstract}
Purpose: To investigate whether different forms of nutritional information displayed on a foodstuff's's front panel packaging affect perceptions of healthiness and purchase intention in Brazilian retail.

Method: An online survey with 399 respondents. Each respondent was shown seven distinct scenarios and two products - breakfast cereal and stuffed cookies. Authentic packaging was used, varying only in the presentation form (GDA, Nutrition Claims, Food Group Information System and complete scenario).

Originality/Relevance: Affecting studies on consumer food decision-making anchored in 'nutritional marketing' strategies (Colby et al., 2010) in a context where concerns regarding healthy food consumption have grown. Nutritional information on the front panel can improve evaluation of food and beverage nutritional value (Roberto, 2012), enhancing product healthiness.

Results: Positively and more consistently adding to the stock of knowledge (complete scenario) regarding perception of the product's healthiness, when compared to an incomplete scenario, leading to a greater purchase intention.

Theoretical/methodological contributions: Nutritional claims are better evaluated by consumers, corroborating Williams (2005) and Feunekes et al. (2008), while contributing both to labelling and packaging studies and to the understanding of the food consumption decision making.

Social/management contributions: The study ratifies nutritional labelling practices that not only attract consumer attention, but also increase healthiness perceptions and purchase intentions, contributing to the promotion of a healthy product image and increased sales, affecting product and brand management as well as social policies for food consumption.

Key words: Front panel. Nutrition labelling. Product marketing. Consumer behaviour.

How to cite the article

American Psychological Association (APA)

Ricci, B. C. da S. M., Brasil, V. S., \& Almeida, S. O. de (2020). Labelling in self-service retail: can the presented form of nutritional information on packaging increase perceptions of healthiness and purchase intention? Brazilian Journal of Marketing, 19(2), 427-447. https://doi.org/10.5585/remark.v19i2.17776. 


\section{Introduction}

While concerns increase worldwide as to the negative effects of poor and unbalanced diets on health and well-being, actions are spreading which encourage consumers to make their own informed choices. According to Savoie et al. (2013), attention to this environment, has led various stakeholders, including industry, governments and non-governmental organisations (NGOs) to develop effective means of assisting customer choice. Within this domain, packaging plays a central part, as it forms a vital communication channel between company and consumer, whilst directly influencing the moment of purchase. Nutritional data present on a label is one such approach aimed at assisting the buyer to make an informed choice. There are, however, other views on how such information may be shown, revealing the lack of consensus on effective presentation (Findling et al., 2018; Ikonen et al., 2019).

Nutritional labelling, notably the type known as front-of-package (FOP), has attracted much research interest, where it is suggested that a properly briefed customer will make informed choices about their food, health (disease prevention) and quality of life. A recently published meta-analysis by Ilkonen et al. (2019) of some 114 subject-related articles concludes that, in general, although information on the front panel might enable customers to identify healthier products, the wider effects on healthier choices is in fact limited. Inquiry into information-led health and nutrition preferences is understood thus, and refers to a strategic area known as nutritional marketing (Colby et al., 2010)

Traditionally, customer foodstuff selection was led by taste and price, rather than any thought of nutrition (Lalor et al., 2011). Changing lifestyle patterns and eating habits, however, linked to changes in physical and cognitive pursuits, have led to a rise in noninfectious health conditions, such as cancer, diabetes and cardiovascular disease (Zafar, Hashim \& Halim, 2016). Additionally, food-related allergies and intolerances linked to overweight and obesity are rising exponentially (Banterle, Cavaliere \& Ricci, 2013). However, trends in food consumption have rapidly altered in the past decade as consumers become increasingly aware that their food choices can potentially affect their health (Marchi et al., 2016).

It is where these elements meet (nutritional information and purchase decision) that theory and practice in this work are examined. We intend here a) to identify whether presented nutritional information changes the perception of healthiness in relation to a product and b) to assess which presentational model is best in order to motivate purchase. Thus, this article joins both academic and managerial contributions on labelling and food consumer 
behaviour, alluding particularly to the national scenario. We will suggest that front panel nutritional information, when compared to the use of a single form of presentation, positively and more consistently affects the perception of a product's healthiness, leading to a greater probability of purchase.

Below is a literature review of the main themes of this study, followed by details of the methodological procedures adopted, data analysis and discussion of results; finally, we present contributions, limitations and implications.

\section{Literature Review}

The three main themes which emerge in this literature review are discussed below, namely nutrition labelling, front panelling, and models of information presentation.

\subsection{Nutritional Labelling}

Consumers' perception of food healthiness can be considered as one of the main determinants in patterns in eating behaviour (Provencher, Polivy \& Herman, 2009). Labelled information, especially that related to nutritional value, can lead the consumer to healthier options (Cowburn \& Stockley, 2005; Drichoutis et al., 2007; Campos, Doxey \& Hammond, 2011). This is a two-way association however: nutrition labelling can promote healthier diets, while individuals who already follow such habits are more likely to look for labelled nutritional information.

In general, consumers find nutrition labelling useful (Byrd-Bredbenner, Wong \& Cottee, 2000), although some report a desire for a simpler way of presenting information (Bitzios et al., 2011). Studies delivered in the United States and in Australia have shown that consumers may have difficulty understanding and interpreting information owing to manufacturers' use of over-technical language (Cowburn \& Stockley, 2005; Campos, Doxey \& Hammond, 2011).

\subsection{Front Panel}

As the supermarket assumes the top position in self-service distribution, packaging gains more importance (Vyth et al., 2010). Assuming the role of silent seller (Gurgel, 2007), 
the nutritional information provided on the packaging may in practice be the only source of information available to the consumer at the point of sale.

Such labelled data can sharpen judgment about the nutritional value of food and beverages (Roberto, 2012), providing consumers with more practical aids than that of nutritional tables, so helping food shoppers to make better-informed decisions (Williams, 2005; Feunekes et al., 2008; Borgmeier \& Westenhoefer, 2009; Vyth et al., 2010; Miklavec et al., 2015).

Buyers value the labelled nutrition information to avoid certain ingredients and to gaug the amount of specific items, especially fat, calories and sugar (Balasubramanian \& Cole, 2002). Labelled information is perceived as the perfect solution to summarizing the entire nutritional profile and to facilitating understanding (Azman \& Sahak, 2014).

Labels, in particular the front panels of the packaging, are considered an important tool in helping buyers make healthier choices (Banterle, Cavaliere \& Ricci, 2013). Research continues into the effectiveness of nutrition labelling, since it cannot be judged fully successful until consumers are conversant with its use, and nutrition information guidelines are included in legislation (Higginson et al., 2002). Attention to nutritional information on the label depends on the objectives and resource limitations that consumers face (Herpern \& Trijp, 2011).

Even if the manufacturer prefers a simple label, the law may require additional information. In Brazil, the Health Regulatory Agency (ANVISA) is the body overseeing labelling information, providing guidance, gathering mandatory information, and further restricting what and in what way may be included in the packaging of products. Its brief is to secure standards in nutrition labelling and to gain consumers trust in what is being communicated. The set of mandatory items on food labelling includes energy value, carbohydrates, proteins, saturated fats, trans fats and sodium. The power to regulate, control and inspect products and services that involve public health risk, including food packaging is devolved to ANVISA through article 8 of Law no. 9782/99

In addition to ANVISA, the Consumer Protection Code (Law 8,078 / 90, art. 6), regulates the labelling of products, stating that every product must show clear, accurate and information in Portuguese, date of expiry, ingredients, manufacturer's name and address among other data, as well as the number of the Federal Inspection Service FIS (ANVISA, 2005; Ferreira \& Lanfer-Marquez, 2007). 
Following the specific guidelines itemised above, industries and retailers using various methods developed their own front panel nutrition information systems, so as to create different consumption profiles. Presenting information in a clear and consistent manner helps consumers while choosing the product (Viswathan \& Hastak, 2002). Additionally, receiving messages related to nutritional issues can facilitate the recognition of such fare as a healthy option (Bolton, Cohen \& Bloom, 2006).

Research shows that consumers often limit their search for information to that contained on the front panel of the packaging, as it is more easily accessed (Kaltcheva, Patino \& Leventhal, 2013). Front panel nutritional information is regarded as strong evidence for the reliability of a food product, whether due to the credibility of the company and the product, or the confirmation of the data contained in the nutritional table (Cannoosamy, Pugo-Gunsam \& Jeewon, 2014).

For the general consumer, who does not follow a special diet or seek a specific nutrient, attention to nutritional information needs to be prompted, and is largely determined by the prominence of specific information within the visual field (Yantis, 2000). The assumption is that the search task is easier if the information stands out over other stimuli displayed on the packaging.

According to Bordenave (2002), the exchange of producer / consumer messaging via the package allows the formation of new concepts and meanings that, if the information set contained in the product is clearly and objectively presented and also within the consumer's grasp, may earn positive reactions.

\subsection{Information Presentation Models}

Information creating expectations, or encouraging the consumer to form an opinion about the nutritional contribution of the product, is known as a claim. Claims are usually highlighted, such as on a front panel splash, and contain objectively communicated information. According to the European Regulation Commission (EC) cited by Zafar, Hasim and Halim (2016), a claim is any message or representation that is not mandatory, including pictorial, graphic or symbolic representations. Faced with so many options at the point of sale, claims help the consumer to save time and may meet health needs when choosing foodstuffs (Spiller, 2011)

Nutrition claims relate to nutritional content, highlighting specific characteristics of a food, usually the presence or level of a nutrient (Williams, 2005), such as "rich in fibre", 
"reduced fat content", "zero sugar". A health claim, according to Zafar, Hashim and Halim (2016), may affirm, suggest or imply that there is a relationship between a food (or one of its ingredients) and health (e.g, "reduces cholesterol" or "prevents osteoporosis"). In Brazil, the use of such health claims is vetoed by ANVISA. Such a ban on their use on the label, however, both in Brazil and elsewhere, has not prevented the proliferation of a large number of potentially confusing and misleading claims open to customer interpretation as means towards healthiness (Williams, 2005). In the Brazilian market this can be clearly seen: several companies create symbols with their own imprints related to the composition of the product and communicate this as an exclusive differential.

Consumers of packaged food products are faced with a variety of front panel nutrition symbols and icons. In general, the purpose of such is to help consumers make healthier choices by simply highlighting information that is of interest. Drawing on nutritional information, Doxey and Hammond (2011) conclude that consumers mindful of a healthy diet expressed a desire for such data in listed form; a larger and more readable impression of the information; use of colour; use of simpler terms; explanations of terms or nutrients; and consistency in label appearance. In another study, Andrews, Burton and Kees (2011) reveal that both the attitude and the purchase intention for products containing any of the information presentation models was significantly stronger than for packaging without an information system.

Evidently, the literature comprises studies involving models for presenting information, its characteristics, effectiveness and acceptance (Keller et al., 1997; Roe, Levy \& Derby, 1999; Herpen \& Trijp, 2011; Hodgkins et al., 2012; Roberto et al., 2012). For the purposes of this study, we have selected those most commonly used by industries in Brazil, each using a form of presenting nutritional information. The forms are described below and, later, in Figure 1.

- Nutrition claims: highlight specific characteristics of a foodstuff, in the form of textual information, usually indicating the presence or level of a nutrient, such as "rich in fibre", "reduced fat content", "zero sugar" (Kaltcheva et al., 2013).

- GDA, or Guideline Daily Amounts: indicates quantity per serving and the corresponding percentage of recommended daily values (\% DV) of sugars, total fats, saturated fats, sodium and energy value (Feunekes et al., 2008).

- Nutrient-specific systems: shows a symbol highlighting the presence or absence of a specific nutrient in the product (Kaltcheva et al., 2013). 
- Food group information systems: textual information via a symbol showing the presence or absence of a certain nutrient (Kaltcheva et al., 2013).

Figure 1 - Examples of Nutrition Information Presentation Models



Source: Prepared by the authors based on the literature review.

The models for presenting the nutritional information described above were used in the current inquiry. The following chapter details the procedures.

\section{Methods}

Using quantitive methodology, such as an online survey, the inquiry centred on the influence of varying presentations of nutritional information to be found on foodstuff packaging, including healthiness perception and purchase intentions. A sample of 399 adults, resident in varying Brazilian states and from diverse age groups, was exposed to seven packages, randomly chosen through Qualtrics software.

We chose to investigate breakfast cereal, since this food category is the subject of several inquiries related to nutrition labelling (Lalor et al., 2010; Zafar, Hashim \& Halim, 2016). In Brazil, consumption per capita of cereals is one of the lowest in Latin America; in 2016 only $0.3 \mathrm{~kg}$ per person according to the Statista website, but with the prospect of 
doubling this by 2020. Although there is significant variation of consumption between the countries, our aim is to verify whether the perceptions in the Brazilian context are consistent with the results of previous studies in the United States and Europe. In this sense, cookies/biscuits are included in this study to test the difference in results for a product viewed as unhealthy.

According to Nielsen, data published by the Brazilian Association of Biscuit, Pasta and Industrialized Breads \& Cakes Industries, show that Brazilians consumed $8.7 \mathrm{~kg}$ of biscuits per capita in 2017, most of this of filled cookies/biscuits, significantly exceeding that of cereals. A sample of twelve adults chosen at random, were asked about a product they habitually bought while aware that the item was not seen as healthy. Seven replied "filled biscuit/cookie". The item was then set against other products of the same brand so as to cancel the brand effect.

Perceptions of healthiness and purchase intention deriving from each of the information systems were tested by the introduction of seven different packages - four from Nescau Cereal and three from Passatempo biscuit. The packages were randomly presented, to avoid creating a suggestion of demand. To authenticate the research, the market packaging of the product was used (Bialkova \& Van Trijp, 2010), keeping all the elements identical and varying only in the form of presentation. Images were devised so as to present totally or partially the nutritional information originally expressed on their actual packaging.

Figure 2 shows each of the systems that were shown on the front panel of each product. In addition to each of the systems illustrated, all products offered front panel options containing all the systems, thus adding the seven scenarios to be evaluated. The varying presentation methods reflected models current in the Brazilian market (GDA, nutrition claims, information system by food group and complete scenario, with the previous three, explained above) 
Figure 2 - Models of packaging used in the study NUTRITION CLAIMS

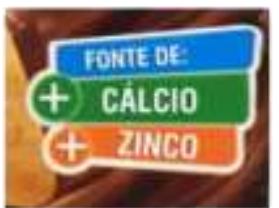

GDA

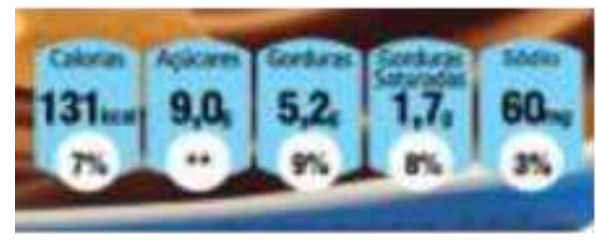

NUTRITION CLAIMS

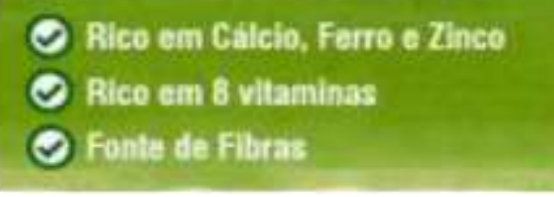

GDA

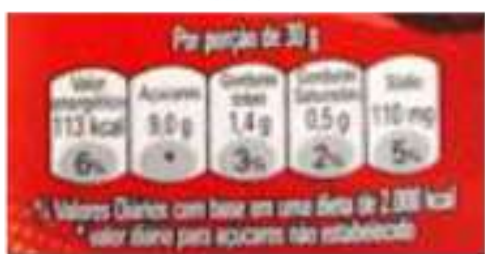

SISTEMA POR TIPO DE PRODUTO

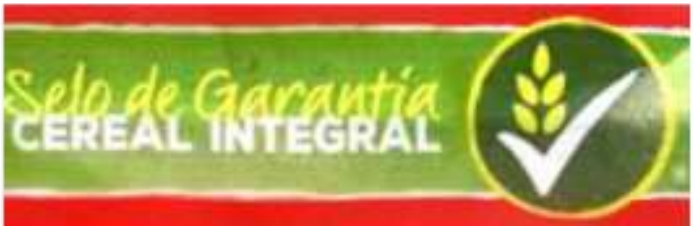

Source: Prepared by the authors.

For the morning cereal, it was decided to apply the variations on the top of the packaging so that the positioning of the information models on the label might not colour perceptions of each presentational form, This approach is in line with methodology of Bialkova and Van Trijp (2010) and Bialkova, Grünert and Van Trijp (2013), whose work concluded that attention of breakfast cereal is more easily attracted when information is thus positioned. For the filled cookie/biscuit, the variations were always applied to the upper righthand part. of the panel. Finally, for each of the packages, the same questions were presented in the same order. Participants were initially informed that seven packages would be presented and that the answers should relate in turn to each and, therefore, they should be individually and carefully considered.

The first question, for each of the seven scenarios, was related to purchase intention. Respondents were asked about the likelihood of their buying the product with the packaging in question on the next trip to the supermarket. Responses were graded on a 5-point likert scale, ranging from "very unlikely" to "very likely", following the pattern used by other empirical studies, in order to measure purchase intent for different product configurations, such as Burton and Pearse (2002), Giehl (2008) and Andrews, Burton and Kees (2011). Next, the respondents indicated the perception of healthiness in relation to the product, with the packaging in question, on a 5-point scale between "not healthy" and "extremely healthy", following the model used by Feunekes et al. (2008). 
Validation of the questionnaire was carried out by experts in the area, following the guidance given by Aaker, Kumar and Day (2004), after consultation with two marketing Ph.D's. In this sense, the instrument was validated drawing upon the literature review, undergoing adjustments following expert guidance. Necessary adjustments were made to aid understanding after reverse translation was carried out by an English language expert. After the validation of the collection instrument, a pre-test was performed (Cooper \& Schindler, 2003) in order to identify possible snags and check understanding. The pre-test was applied personally to ten adults, allowing for observation of reactions and attitudes and identification of areas for improvement. The survey was disseminated through social networks, especially Facebook, targeting subjects from all over Brazil, with different demographic profiles.

The comparative analysis between the effects of the different forms of presentation of nutritional information on the perception of healthiness and the purchase intention was based on the application of the paired t-test. According to Hair et al. (2009), this test is appropriate when seeking to understand the variations in averages observed in a metric variable (for example, perception of healthiness and purchase intention) resulting from different levels or treatments of a certain factor (in this case, the form of nutritional presentation ). By comparing a maximum of two subject groups and using only one independent variable at a time, this approach has few limitations.

\section{Analysis of Results}

Results are presented below in three categories: 1) characterization of the sample and consumption profile; 2) perceptions of healthiness; and, 3) consumption intentions.

\subsection{Sample and Consumption Profile}

The respondents were mostly female (78.7\%), with an average age of 35.94 years, with the youngest respondent aged eighteen and the eldest fifty-seven. $79.7 \%$ of respondents had completed at least higher education (included within this group specialization, master's or doctorate). Only $1.8 \%$ of respondents had not completed secondary education; $8.8 \%$ had completed only secondary education and $9.8 \%$ of respondents had not completed higher education. Most respondents had a monthly family income of above R \$ 3,520.01 (72.3\%). Of these, 31.8\% had family earnings between 4 and 10 times minimum salary. The range considered for the study were in line with the recommendations of the Brazilian Institute of 
Geography and Statistics (IBGE 2015). Of the 399 respondents, 87.2\% said they were in employment.

When questioned on the frequency with which they consult the nutritional information at the moment of purchase, $56.7 \%$ of the respondents said they "always" or "almost always" read the nutritional information when purchasing a foodstuff. $38.1 \%$, on the other hand, admitted reading such nutritional information only when preparing the food. Therefore, the act of purchase is the moment of greatest consultation, as identified in the studies by Drichoutis, Lazaridis and Nayga (2005), Mannell et al. (2006); Drichoutis et al. (2007) and Giehl (2008).

Similarly, the inquiry focussed on the frequency with which buyers use nutritional information when choosing between two products at the moment of purchase. According to Higginson et al. (2002), the most common consumer reason for viewing nutrition labelling is to compare products. The result showed that $50.7 \%$ of respondents "always" or "often" consult nutritional information to choose between two foodstuffs, and $21.1 \%$ "sometimes" compare such data to decide between more than one product. Such results corroborate those of Drichoutis, Lazaridis and Nayga (2005) and Mannell et al. (2006), in which the respondents said that nutritional information was an important factor when choosing food.

\subsection{Perceptions of Healthiness}

A scale was used from previous similar studies (Feunekes et al., 2008; Kaltcheva, Patino \& Leventhal, 2013) to analyse perceptions of healthiness. As a device for data analysis, a paired $\mathrm{t}$ test produced averages for healthiness perceptions of each nutritional form presented on the packages. Table 1 shows the results of healthiness perceptions in relation to each of the packaging items presented for the product Cereal Matinal (Breakfast Cereal). All variations were significant.

In a situation where the consumer is faced with one package containing only the GDA $(\mathrm{M}=2.09 ; \mathrm{SD}=1.078)$ and another that has textual information in addition to the GDA $(\mathrm{M}=$ $2.56 ; \mathrm{SD}=1.146)$, the additional data creates the perception that the product is healthier. In the contrast between the packaging with only GDA $(\mathrm{M}=2.09 ; \mathrm{SD}=1.078)$ and the alternative which increases information by including product group $(\mathrm{M}=2.42$; $\mathrm{DP}=1.159)$, the packaging with the guarantee seal increases the perception of product healthiness. If we compare the packaging containing the GDA plus textual information to that containing the system by product group $(\mathrm{M}=2.42 ; \mathrm{SD}=1.159)$, the first $(\mathrm{M}=2.56 ; \mathrm{SD}=1.146)$ performs 
best. The system by product group is only seen as relating to a healthier product $(\mathrm{M}=2.42$; $\mathrm{SD}=1.159)$ compared to packaging that relies only on GDA $(\mathrm{M}=2.09 ; \mathrm{DP}=1.078)$. In other words, the more information on the packaging, the more the consumer perceives the product's healthiness. To this extent, we suggest that the presence of more information (the three forms of presentation being used) encouraged the perception of product healthiness $(\mathrm{M}=2.73 ; \mathrm{SD}=$ 1.261), with the packaging being perceived as containing a healthier product.

Table 1 - Perception of healthiness - morning cereal

\begin{tabular}{|c|c|c|c|c|c|}
\hline & Average & $\mathrm{N}$ & DP & paired t-test & sig. \\
\hline GDA & 2.09 & 399 & 1.078 & \multirow{2}{*}{9.666} & \multirow{2}{*}{.000} \\
\hline GDA_INFO & 2.56 & 399 & 1.146 & & \\
\hline GDA & 2.09 & 399 & 1.078 & \multirow{2}{*}{7.173} & \multirow{2}{*}{.000} \\
\hline GDA_SC & 2.42 & 399 & 1.159 & & \\
\hline GDA & 2.09 & 399 & 1.078 & \multirow{2}{*}{11.342} & \multirow{2}{*}{.000} \\
\hline COMPLETE SCENARIO & 2.73 & 399 & 1.261 & & \\
\hline GDA_INFO & 2.56 & 399 & 1.146 & \multirow{2}{*}{3.271} & \multirow{2}{*}{.001} \\
\hline GDA_SC & 2.42 & 399 & 1.159 & & \\
\hline GDA_INFO & 2.56 & 399 & 1.146 & \multirow{2}{*}{3.766} & \multirow{2}{*}{.000} \\
\hline COMPLETE SCENARIO & 2.73 & 399 & 1.261 & & \\
\hline GDA_SC & 2.42 & 399 & 1.159 & \multirow{2}{*}{6.550} & \multirow{2}{*}{.000} \\
\hline COMPLETE SCENARIO & 2.73 & 399 & 1.261 & & \\
\hline
\end{tabular}

Source: Data collection

GDA= front panel, GDA only; GDA_INFO= front panel with GDA plus 'nutrition claims'; GDA_SC= front panel with GDA plus information system for each foodstuff.

The result for all paired t-tests indicated that, when comparing the GDA-only packaging with that bearing GDA plus any of the other information systems, in all cases, the latter increased healthiness perceptions of the product. The GDA-only packaging had the weakest impact on the perception of healthiness $(\mathrm{M}=2.09 ; \mathrm{SD}=1.078)$. It is likely that textual information aids understanding of product content, since consumers may labour with numerical and percentage information, such as in GDA. A similar result was described in Bitzios et al. (2011).

The system per food group, which serves as a seal of quality assurance, or even health, had less impact on the perception of healthiness compared to a form of presentation considered to be simpler, as it contains only textual information, as is the case with nutrition 
claims, when we analyze breakfast cereal. There was a similar reaction when analysing the filled biscuit product. The paired t-test was repeated in order to compare either presentation of nutritional information. All differences were significant, as shown in Table 2.

Table 2 - Perceptions of healthiness for filled cookie/biscuit

\begin{tabular}{l|ccccc}
\hline & Average & $\mathrm{N}$ & $\mathrm{DP}$ & paired t-test & sig. \\
\hline GDA & 1.72 & 399 & .909 & \multirow{2}{*}{.524} & .000 \\
\hline INFO & 1.92 & 399 & 1.053 & & .000 \\
\hline GDA & 1.72 & 399 & .909 & \multirow{2}{*}{6.249} & .024 \\
\hline CENÁRIO COMPLETO & 2.01 & 399 & 1.133 & & \\
\hline INFO & 1.92 & 399 & 1.053 & 2.266 & \\
\hline CENÁRIO COMPLETO & 2.01 & 399 & 1.133 & & \\
\hline
\end{tabular}

Source: Data collection.

GDA= front panel, GDA only; GDA_INFO= front panel with GDA plus 'nutrition claims'; GDA_SC= front panel with GDA plus information system for each foodstuff.

The result was repeated for the filled cookie/biscuit: the more information on the packaging, the greater the perception of product healthiness. We conclude this since the packaging with all forms of presentation (complete scenario) achieved the highest average (M $=2.01 ; \mathrm{SD}=1.133)$, both in comparison with the GDA $(\mathrm{M}=1.72 ; \mathrm{SD}=0.909)$ and with the package containing only textual information $(\mathrm{M}=1.92 ; \mathrm{SD}=1.053)$. Upon comparing packaging containing the GDA $(\mathrm{M}=1.72 ; \mathrm{SD}=0.909)$ and that showing a splash with textual information $(\mathrm{M}=1.92 ; \mathrm{SD}=1.053)$, the latter was perceived as the healthier.

\subsection{Likely to Buy}

Purchase intention was then checked for each package. The t-test was applied to gauge the influence on purchase intention from varying forms of nutritional information presented on the packaging, via the complete scenario, and with all the formats present.

Initially, analysis of averages recorded for the intention to purchase the Cereal Matinal product was carried out (Table 3). A paired t test was then delivered comparing the differences in purchase intention between each of the forms of information presentation, from the simplest (GDA) to the most exhaustive of the systems (complete context). The average was 2.11 in the simplest ( $\mathrm{DP}=1.228$ ), that is, the purchase intention is lower in the simplest and higher in the more complete $(\mathrm{M}=2.60 ; \mathrm{DP}=1.382)$. The variance is significant, and suggests that with more information, purchase intention increases. This result reinforces that 
found in the study by Bialkova, Grunert and Van Trijp (2013) i.e. that attention increases when there is a combination of information systems.

Table 3 - Likelihood of buying morning cereal product

\begin{tabular}{|c|c|c|c|c|c|}
\hline & AV. & $\mathrm{N}$ & DP & paired t-test & sig. \\
\hline GDA & 2.11 & 399 & 1.228 & \multirow{2}{*}{7.788} & \multirow{2}{*}{.000} \\
\hline GDA_INFO & 2.47 & 399 & 1.309 & & \\
\hline GDA & 2.11 & 399 & 1.228 & \multirow{2}{*}{3.790} & \multirow{2}{*}{.000} \\
\hline GDA_SC & 2.28 & 399 & 1.278 & & \\
\hline GDA & 2.11 & 399 & 1.228 & \multirow{2}{*}{8.819} & \multirow{2}{*}{.000} \\
\hline COMPLETE SCENARIO & 2.60 & 399 & 1.382 & & \\
\hline GDA_INFO. & 2.47 & 399 & 1.309 & \multirow{2}{*}{4.997} & \multirow{2}{*}{.000} \\
\hline GDA_SC. & 2.28 & 399 & 1.278 & & \\
\hline GDA_INFO. & 2.47 & 399 & 1.309 & \multirow{2}{*}{2.910} & \multirow{2}{*}{.004} \\
\hline COMPLETE SCENARIO & 2.60 & 399 & 1.382 & & \\
\hline GDA_SC & 2.28 & 399 & 1.278 & \multirow{2}{*}{7.262} & \multirow{2}{*}{.000} \\
\hline COMPLETE SCENARIO & 2.60 & 399 & 1.382 & & \\
\hline
\end{tabular}

Source: Data collection.

GDA= front panel, GDA only; GDA_INFO= front panel with GDA plus 'nutrition claims'; GDA_SC= front panel with GDA plus information system for each foodstuff.

Table 4 shows the results of the analysis for the filled cookie/biscuit. As for the cereal, a paired t test was delivered comparing the differences in purchase intention prompted by the forms of nutritional presentation on the packaging. Since this foodstuff is classified as unhealthy, it was not tested with the short indicator symbol (information by food group); this format denotes the healthiness of a particular product. 
Table 4 - Likelihood of buying filled cookie/biscuit

\begin{tabular}{l|lllll}
\hline & & & & paired t- \\
& AV. & N & DP & test & sig. \\
\hline GDA & 1.94 & 399 & 1.160 & & \\
INFO & 2.09 & 399 & 1.256 & 3.466 & .001 \\
\hline GDA & 1.94 & 399 & 1.160 & & \\
\hline COMPLETE SCENARIO & 2.27 & 399 & 1.341 & & .000 \\
\hline INFO & 2.09 & 399 & 1.256 & 4.974 & .000 \\
\hline COMPLETE SCENARIO & 2.27 & 399 & 1.341 & & \\
\hline
\end{tabular}

Source: Data collection.

GDA= front panel, GDA only; GDA_INFO= front panel with GDA plus 'nutrition claims'; GDA_SC= front panel with GDA plus information system for each foodstuff.

In the case of the biscuit, a fuller set of information enhances the likely purchase of the product $(\mathrm{M}=2.27 ; \mathrm{SD}=1.341)$ as much as for the GDA bearing packaging $(\mathrm{M}=1.94 ; \mathrm{SD}=$ $1.160)$, as for packaging displaying only textual information $(\mathrm{M}=2.09 ; \mathrm{SD}=1.256)$. That is, the intention to purchase a product viewed as unhealthy increases when the packaging shows more information.

On packaging showing only GDA $(\mathrm{M}=2.09$; $\mathrm{SD}=1.256)$ or nutrition-only claims $(\mathrm{M}$ $=1.94 ; \mathrm{SD}=1.156$ ), such textual information produces the highest probability of purchase. Therefore, where the company has limited label space for more than one information set, the use of nutrition claims is the most appropriate, producing the highest probability of purchase. Simply put, we conclude that the more information available, the greater the intention to purchase a product.

\section{Discussion of results}

Research involving nutritional information draws on three major themes, namely: behaviour of the foodstuff consumer, product marketing and nutrition labelling. The convergence of these themes has been noted as of important academic, managerial and social relevance, hence motivating this study.

In the United States and Europe, food manufacturers varyingly highlight nutritional information on the front panel of the label of their products, and the consumer already familiar with certain models (Leathwood et al., 2007) has greater ease in reading and 
understanding the information therein. In Brazil, there is still space for exploring and deepening these themes.

Thus, the aim of this inquiry was to understand: (a) if different sets of nutritional information on the front panel of food packaging affect notions of healthiness, and (b) which front panel informational model is best to increase the likelihood of foodstuff purchase. Both objectives were achieved, since it seems to be proven that the inclusion of a fuller information set on the front panel of packaging increases the foodstuff's perceived links to healthiness.

Moreover, should the company not choose or, due to limited space, be unable to combine varying methods of information display (complete scenario), the one most likely to increase perceptions of product healthiness is the combination of GDA, with textual information, expressing its nutritional differentials (for example, rich in calcium, contains 8 vitamins, fibre source etc.)

The information display perceived as implying healthier food choices contained claims, widely used by foodstuff marketing in Brazil. As for the apparent overall healthiness of the product, the most effective means was the complete packaging, which communicates the attributes of nutritional differentials. This finding was repeated both in relation to breakfast cereals and to stuffed cookies/biscuits and is similar to those found in other studies (Fidling et al., 2018; Ikonen et al., 2019). Such studies confirm that nutritional information on the front panel of the packaging, regardless of type, increases its perception of wholesomeness, and in general, the nutrition claims and the information system per food group are superior to GDA.

By highlighting the wholesome value of foodstuffs, nutrition claims are objective and easy to understand, strengthening the perception of product healthiness. Conversely, although the GDA provides access to part of the nutritional table, it also reveals items not sought by the consumer (sugar, salt, fats and calories), and can be associated with an unwholesome product.

Purchase intention was tested for each data form presented from the information under analysis (nutrition claims, GDA, guarantee seal and complete label), implying that the highest probability of purchase results from the most complete label. Packages grouping together all the tested presentation models were identified as not only creating the greatest perception of healthiness but also the strongest intention to purchase. Therefore, the more information, the better. In general, the relationship between the presentation of nutritional information and a greater purchase intention has produced conflicting results in the literature. Graham et al. (2016) and Fidling et al. (2018) do not support the hypothesis that front panel information 
will increase the likelihood of purchase. Ikonen et al. (2019) assert that both nutrition claims as well as the information system by type of product (guarantee seal) are positively allied to purchase intention. In general, the relationship between the presentation of nutritional information and a greater purchase intention has produced conflicting results in the literature. Graham et al. (2016) and Fidling et al. (2018) do not support the hypothesis that front panel information will increase the likelihood of purchase. Ikonen et al. (2019) assert that both nutrition claims as well as the information system by type of product (guarantee seal) are positively allied to purchase intention.

Interestingly, when comparing the information system by food group to that of solely textual information (nutrition claims), results suggest that the product with packaging conveying just textual information is more likely to be bought. These results suggest a potentially positive outcome for any information on the front panel. That is, with recourse to this inquiry, the purchase intention increased when any of the nutritional icons was reproduced. This result supports the potential value of front panel information (provided it is not misleading) in apprising consumers who need to judge and to decide, as also pointed out by Keller et al. (1997).

Should the company choose not to, or is unable to present, due to space restriction, several nutritional items of information on the front panel, it is recommended they rely on nutrition claims, a model that is better evaluated by consumers when compared to others. This result is in line with the studies by Williams (2005) and Feunekes et al. (2008), which recommend a simpler information format on the front panel and more detailed systems on the back. This can help consumers make decisions more quickly, but also provide more detailed information, should they wish it.

\subsection{Contributions}

As for academic contributions, this study collaborates with research in the area of nutrition labeling and consumer buying behavior. Its results contribute, especially, to studies in the Brazilian scenario, which are still scarce.

Regarding their managerial contributions, the results of the present study represent contributions to the Brazilian market, especially to the marketing and product development departments. The study claims insights and confirms nutrition labelling practices that not only attract consumer attention, but also increase the perception of healthiness and purchase intent. Its use in practice thus contributes to promoting a healthy product image (provided the 
information on the label is consistent with what is highlighted on the front panel) as well as increasing sales.

In a self-service environment, where packaging is responsible for attracting, informing and winning over the buyer, the results of this study contribute with guidelines that can help industries find and use the best models to achieve positive results. Since the present study shows that properly exposed nutritional information on the packaging, generates an increase in sales, this result is also positive for the retailer.

This study also contains social contributions, given results suggest that consumers' purchase intentions are closely related to the amount of information exhibited on the food label, not necessarily linked to its healthiness. Thus, managers should consider how to convert consumer interest into detailed information leading to healthier consumption decisions, reducing risks of obesity and foodstuff-related disease in society.

\subsection{Limitations and Future Research}

This study has its limitations. One such is data collection within social networking environments, restricting inquiry to a certain consumer type who uses such networks, and is set within the scope of the research distribution. One should also consider questions of response time and the respondent's attention in social networks. Another limiting factor refers to the way in which the packaging was presented to the respondents, and the fact that the respondent saw other types of packaging within the context of the study, even though randomized, may have influenced the evaluation of subsequent packaging.

Regarding the filter by which the respondents were selected, it is also possible to identify as a limitation of this study the fact that previous safeguards on the researched foods were not considered, thus, consumers who have no taste for the researched foods may have been selected to participate in the study. and, eventually, to respond in a skewed manner to the question about the intention to purchase said products. Future studies may consider different forms of packaging presentation, such as by groups, for example, aiming to mitigate these effects, in addition to stricter filtering of respondents.

Another limiting factor of the study may be the exclusion of control variables such as intimacy with the product or brand, as well as duration of product use and the parents' knowledge of nutrition, in addition to the possibility that related children themselves have medical conditions. for diet or food restriction. Such conditions could have influenced parents' 
perception of food healthiness. Thus, it is suggested that future studies include these assessments.

Other aspects not researched in this project and which may be included in future inquiries question how the amount, and not the type of nutritional information, impacts the consumer's perception of healthiness. Thus, it could be identified whether there are limitations on how far the consumer recognises which information is, in fact, fundamental / determinant, resulting in an option based on the perception that "the more information, the better". However, for future research, we propose the testing of nutrition labelling for consumers with dietary restrictions (such as lactose intolerance, celiac disease and other allergies), in order to compare results. It would also be profitable to explore the same scenarios by testing perceptions of healthy and unhealthy products by conducting a comparative study of the impacts of front panel information on extremely healthy and unhealthy items. Issues involving the system's placement on the front panel, as well as variations in formats and colours would also be of great value if applied to the Brazilian scenario.

\section{References}

Aaker, D.A., Kumar, V. \& Day, G.S. (2004). Pesquisa de Marketing. (2a ed.). São Paulo: Atlas.

ABIMAPI (2019). Associação Brasileira das Indústrias de Biscoitos, Massas Alimentícias e

Pães \& Bolos. Recuperado a partir de https://www.abimapi.com.br/.

Andrews, J.C., Burton, S. \& Kees, J. (2011). Is simpler always better? Consumer evaluations of front-of-package nutrition symbols. Journal of Public \& Marketing, 30(2), 175-190.

Azman, N. \& Sahak, S. (2014). Nutritional Label and Consumer Buying Decision: A Preliminary Review. Procedia - Social and Behavioral Sciences, 490-498.

Balasubramanian, S.K. \& Cole, C. (2002). Consumers' search and use of nutrition information: The challenge and promise of the nutrition labeling and education act. Journal of Marketing, 66 (3), 112-127.

Banterle, A., Cavaliere, A. \& Ricci, E.C. (2013). Food labelled information: An empirical analysis of consumer preferences. International Journal on Food System Dynamics, 3 (2), 156-170.

Bialkova, S. \& VanTrijp, H. (2010). What determines consumer attention to nutrition labels? Food Quality and Preference, 21 (8), 1042-1051.

Bialkova, S., Grunert, K.G. \& Van Trijp, H. (2013). Standing out in the crowd: The effect of information clutter on consumer attention for front-of-pack nutrition labels. Food Policy, 41, 65-74.

Bitzios, M., Fraser, I. \& Haddock-Fraser, J. (2011). Functional ingredients and food choice: Results from a dual-mode study employing means-end-chain analysis and a choice experiment. Food Policy, 36 (5), 715-725.

Bolton, L.E., Cohen, J.B. \& Bloom, P.N. (2006). Does marketing products as remedies create "Get out of jail free cards"? Journal of Consumer Research, 33, 71-81.

Bordenave, J.E.D. (2002). Além dos meios e mensagens. (10a ed.). Petrópolis: Vozes. 
Borgmeier, I. \& Westenhoefer, J. (2009). Impact of different food label formats on healthiness evaluation and food choice of consumers: a randomized-controlled study. $B M C$ Public Health, 9 (1), 1-12.

Burton, M. \& Pearse, D. (2002). Consumer attitudes towards genetic modification, functional foods, and microorganisms: A Choice modeling experiment for beer. AgBioForum, 5 (2), 51- 58 .

Byrd-Bredbenner, C., Wong, A. \& Cottee, P. (2000). Consumer understanding of US and EU nutrition labels. British Food Journal, 102 (8), 615-629.

Campos, S., Doxey, J. \& Hammond, D. (2011). Nutrition labels on pre-packaged foods: a systematic review. Public Health Nutrition, 14 (8), 1496-1506.

Cannoosamy, K., Pugo-Gunsam, P. \& Jeewon, R. (2014). Consumer Knowledge and Attitudes toward Nutritional Labels. Journal of Nutrition Education and Behaviour, 46 (5), 334-340.

Cavaliere, A., Ricci, E.C., \& Banterle, A. (2015). Nutrition and health claims: Who is interested? An empirical analysis of consumer preferences in Italy. Food Quality and Preference, 41, 44-51.

Colby, S. E. et al. (2010). Nutrition marketing on food labels. Journal of Nutrition Education and Behavior, v. 42, n. 2, p. 92-98.

Cooper, D. R. \& Schindler, P.S. (2003). Métodos de Pesquisa em Administração. Porto Alegre: Bookman.

Cowburn, G. \& Stockley, L. (2005). Consumer understanding and use of nutrition labeling: a systematic review. Public Health Nutrition, Wallingford, 16 (2), 21-28.

Drichoutis, A.C., Lazaridis, P. \& Nayga, R. Jr. (2005). Nutrition knowledge and consumer use of nutritional food labels. European Review of Agricultural Economics, 32 (1), 93-118.

Drichoutis, A.C., Lazaridis, P. \& Nayga, R. Jr. (2006). Consumer's use of nutritional labels: a review of research studies and issues. Academy of Marketing Science Review, 2006 (9), 122.

Drichoutis, A.C. et al. (2008). A theoretical and empirical investigation of nutrition label use. The European Journal of Health Economics. Eur. J. Health Econ., 9, 293-304.

Ferreira, A.B. \& Lanfer-Marquez, U.M. (2007). Legislação Brasileira referente à rotulagem nutricional de alimentos. Revista de Nutrição, 20 (1), 83-93.

Feunekes, G.I. J., Gortemaker, I. A., Willems, A.A., Lion, R \& Kommer, M. (2008) Front-ofpack nutrition labeling: Testing effectiveness of different nutrition labelling formats frontof-pack in four European countries. Appetite, 50, 57-70.

Fidling, M.G. et al. (2018). Comparing Five Front-of-Pack Nutrition Labes' Influence on Consumers' Perceptions and Purchase Intentions. Preventive Medicne, 106, 114-121, https://doi.org/10.1016/j.ypmed.2017.10.022.

Giehl, R. B. T. (2008). A importância das informações nutricionais nos rótulos de alimentos na intenção de compra do consumidor. (Dissertação de Mestrado). Faculdade de Administração e Negócios - Pontifícia Universidade Católica do Rio Grande do Sul, Porto Alegre, RS, Brasil.

Graham, D.J. et al. (2016). Impact of Explained versus Unexplained Front-of-Package Butrition Labels on Parent and Child Food Choices: a randomized trial. Public Health Nutrition. 20 (5), 774-785.

Gurgel, F.A. (2007). Administração da Embalagem. São Paulo: Thomson Learning. Hair J. et al. (2009). Análise Multivariada de Dados. (6a ed). Porto Alegre: Bookman.

Herpen, E. \& Van Trijp, H. (2011). Front-of-pack nutrition labels. Their effect on attention and choices when consumers have varying goals and time constraints. Appetite, 57(1), 148160. 
Higginson, C., Rayner, M., Draper, S. \& Kirk, T. R. (2002). The Nutrition label - which information is looked at? Nutrition and Food Science, 32 (3), 92-99.

Ikonen, L., Sotgiu, F., Aydinli, A. \& Verlegh, P. (2019). Consumer effects of front-ofpackage nutrition labeling: an interdisciplinary meta-analysis. Journal of the Academy of Marketing Science, https://doi.org/10.1007/s11747-019-00663-9.

Kaltcheva, M.B., Kaltcheva, V., Patino, A. \& Leventhal, R. (2013). Front-of-package product labels: influences of varying nutritional food labels on parental decisions. Journal of Product \& Brand Management, 352-361.

Keller, S. B. et al. (1997). The effects of nutrition package claims, nutrition facts panels, and motivation to process nutrition information on consumer product evaluations. Journal of Public Policy \& Marketing, 256-269.

Lalor, F., Madden, C., McKenzie, K. \& Wall, P. G. (2001). Health claims on foodstuffs: A focus group study of consumer attitudes. Journal of Functional Foods, 3, 56-59.

Leathwood, P. D. et al. (2007). Consumer understanding of nutrition and health claims: sources of evidence. British Journal of Nutrition, 98 (3), 474-484.

Mannell, A. et al. (2006). French consumers' use of nutrition labels. Nutrition \& Food Science, 36 (3), 159-168.

Marchi, E., Caputo, V., Nayga R. Jr. \& Banterle, A. (2016). Time preferences and food choices: evidence from a choice experiment. Food Policy, 62, 99-109.

Miklavec, K.; Pravst, I.; Grunert, K.G.; Klopcic, M. \& Pohar, J. (2015). The influence of health claims and nutritional composition on consumer's yoghurt preferences. Food Quality and Preference, 43, 25-33.

Provencher, V., Polivy, J., \& Herman, C. P. (2009). Perceived healthiness of food. If it's healthy, you can eat more! Appetite, 52 (2), 340-344.

Roberto, C.A., Bragg, M.A., Schwartz, M.B., Swamans, M.J., Musicus, A., Novak, N. \& Brownell, K.D. (2012). Facts up front versus traffic light food labels: a randomized controlled trial. American Journal of Preventive Medicine, 43 (2), 134-141.

Savoie, N., Barlow, K., Hervey, K., Binnie, M. \& Pasut, L. (2013). Consumer perceptions of front-of-package labelling systems and healthiness of foods. Canadian Journal of Public Health, 104 (5), 359-363.

Spiller, S. A. (2011). Opportunity cost consideration. Journal of Consumer Research, 38, $595-610$.

Statista (2019). Breakfast Cereals. Recuperado a partir de https://www.statista.com/outlook/40090100/115/breakfast-cereals/brazil.

Viswanathan, M. \& Hastak, M. (2002). The role of summary information in facilitating consumers' comprehension of nutrition information. Journal of Public Policy \& Marketing, 21, (2), 305-318.

Vyth, E.L. et al. (2010). Actual use of a front-of-pack nutrition logo in the supermarket: consumer's motives in food choice. Public Health Nutrition, 13, p. 1882-1889.

Williams, P. (2005). Consumer understanding and use of health claims for foods. Nutrition Reviews, 63 (7), 256-264.

Yantis, S. (2000). Goal-directed and stimulus-driven determinants of attentional control. Attention and Performance, 18, 73-103.

Zafar, M.Z., Hashim, N.A., \& Halim, F. (2016) Consumer's perception toward health claims for healthy food selection. Journal of Scientific Research and Development, 3, 57-67. 


\title{
ÓTULOS NO VAREJO DE AUTOSSERVIÇO: A FORMA DE APRESENTAÇÃO DA INFORMAÇÃO NUTRICIONAL NA EMBALAGEM PODE AUMENTAR A PERCEPÇÃO DE SAUDABILIDADE E A INTENÇÃO DE COMPRA?
}

\author{
Bianca Castro da Silva Maraninchi Ricci \\ Mestre em Administração/Marketing pelo PPGAd/PUCRS, Porto Alegre, RS, Brasil. \\ bianca.ricci@acad.pucrs.br \\ Vinícius Sittoni Brasil \\ Doutor em Administração/Marketing pelo PPGA/UFRGS. Professor Titular da Escola de Negócios da Pontifícia \\ Universidade Católica do Rio Grande do Sul, Porto Alegre, RS, Brasil. \\ vinicius@pucrs.br \\ Stefânia Ordovás de Almeida \\ Doutora em Administração/Marketing pela FEA/USP. Professora do Programa de Pós-Graduação em \\ Administração - PPGAd - Escola de Negócios da Pontifícia Universidade Católica do Rio Grande do Sul, Porto Alegre, RS, \\ Brasil. \\ stefania.almeida@pucrs.br
}

Objetivo: Investigar se diferentes formas de apresentação da informação nutricional no painel frontal das embalagens de alimentos interferem na percepção de saudabilidade e na intenção de compra no varejo brasileiro. Método: Survey online com 399 respondentes. Cada um analisou sete embalagens distintas e dois produtos cereal matinal e biscoito recheado. Utilizaram-se embalagens reais com a aplicação de diferentes formas de apresentação da informação nutricional (GDA, nutrition claims, sistema de informação por grupo de alimento e cenário completo, incluindo todas as formas em conjunto).

Originalidade/Relevância: Impacta os estudos sobre tomada de decisão do consumidor de alimentos ancorados em estratégias de "marketing nutricional" (Colby et al., 2010), em um contexto com preocupação crescente com o consumo de alimentos mais saudáveis. Informações nutricionais no painel frontal podem melhorar a precisão de julgamentos sobre a qualidade nutricional dos alimentos e bebidas (Roberto, 2012), reforçando a saudabilidade dos produtos.

Resultados: A presença de uma combinação de diferentes formas de apresentação (cenário completo) impactou positivamente e de forma mais consistente a percepção de saudabilidade do produto, quando comparada com o uso de uma única forma de apresentação, considerando-se o produto mais saudável e igualmente levando a uma maior probabilidade de compra.

Contribuições teóricas/metodológicas: É indicado utilizar os nutrition claims, melhor avaliado pelos consumidores, corroborando Williams (2005) e Feunekes, Gortemaker, Willems, Lion e Kommer (2008). Contribui-se, assim, tanto para estudos sobre rotulagem e embalagens como na compreensão do processo de decisão de compra sobre alimentos.

Contribuições sociais/para a gestão: $O$ estudo ratifica práticas de rotulagem nutricional que atraem a atenção do consumidor e aumentam a percepção de saudabilidade e a intenção de compra, contribuindo para a promoção de uma imagem de produto saudável e o aumento das vendas, com impactos para a gestão de produtos e marcas e políticas sociais sobre alimentação.

Palavras-chave: Embalagem. Rotulagem nutricional. Marketing de produto. Comportamento do consumidor de alimentos.

\section{Como citar}

American Psychological Association (APA)

Ricci, B. M., Brasil, V. S., \& Almeida, S. O. de (2020). Rótulos no varejo de autosserviço: a forma de apresentação da informação nutricional na embalagem pode aumentar a percepção de saudabilidade e a intenção de compra? Revista Brasileira de Marketing, 19(2), 422-444. https://doi.org/10.5585/remark.v19i2.17776. 


\section{Introdução}

Com a crescente preocupação mundial com os impactos decorrentes de uma alimentação inadequada ou pouco equilibrada na saúde das pessoas, ampliaram-se as iniciativas que permitam ao consumidor uma tomada de decisão consciente e corretamente informada. Conforme Savoie et al. (2013), o reconhecimento dessa importância tem levado diferentes stakeholders, incluindo indústria, governos e organizações não-governamentais, a desenvolverem maneiras mais consistentes de auxiliar o consumidor em suas decisões. Neste cenário, as embalagens têm um papel fundamental, visto que muitas vezes representam um importante canal de comunicação entre a empresa e o comprador, ao mesmo tempo em que impactam diretamente o momento da compra. A informação nutricional presente nos rótulos tem sido uma das abordagens utilizadas para ampliar a capacidade do consumidor tomar decisões mais conscientes e corretas. Por outro lado, observa-se uma diversidade de formas de apresentação dessas informações, demonstrando a falta de consenso sobre o formato mais eficaz de apresentá-las (Findling et al., 2018; Ikonen et al., 2019).

Estudos sobre rotulagem nutricional vêm ocupando um lugar de destaque nas pesquisas acadêmicas, sobretudo acerca do chamado "painel frontal das embalagens" ("frontof-package" - FOP). O princípio básico assumido é de que um consumidor adequadamente informado decide melhor, reforçando a relação positiva entre alimentação, saúde (prevenção de doenças) e qualidade de vida. Em uma meta análise publicada recentemente, Ilkonen et al. (2019) analisaram 114 artigos relacionados ao tema e concluíram, em linhas gerais, que as informações do painel frontal auxiliam os consumidores a identificar produtos mais saudáveis; contudo, o impacto em escolhas mais saudáveis de fato é algo limitado. Compreende-se, assim, a relevância de estudos sobre informações e decisões relacionadas à saúde e à nutrição, abarcando um campo estratégico que podemos chamar de marketing nutricional (Colby et al., 2010).

Tradicionalmente, os critérios de seleção de um alimento por parte do consumidor estavam baseados no sabor e no preço, em vez de considerar questões nutricionais (Lalor et al., 2011). A mudança do padrão de estilo de vida e comportamento alimentar, bem como a alteração das atividades físicas e cognitivas, tornou-se a causa de doenças não transmissíveis, como câncer, diabetes e doenças cardiovasculares (Zafar, Hashim \& Halim, 2016). Problemas relacionados a alergias, intolerâncias, doenças relacionadas à alimentação, sobrepeso e obesidade vêm crescendo rapidamente (Banterle, Cavaliere \& Ricci, 2013). Por outro lado, as tendências de consumo alimentar mudaram rapidamente na última década, devido ao aumento 
do interesse do consumidor sobre o que está comendo, por estar cada vez mais consciente que suas escolhas alimentares podem afetar potencialmente a sua saúde (Marchi et al., 2016).

$\mathrm{Na}$ interseção entre esses elementos (informações nutricionais no painel frontal das embalagens e decisão de compra), a lacuna teórica e as contribuições práticas deste trabalho se desdobram. Diante disso, os objetivos deste estudo são: a) identificar se a forma de apresentação da informação nutricional no painel frontal de uma embalagem altera a percepção de saudabilidade em relação a um produto e b) avaliar qual o modelo mais adequado de apresentar ou destacar informações no painel frontal para aumentar a probabilidade de compra. Para responder a esses objetivos, este artigo traz contribuições acadêmicas e gerenciais para as pesquisas em rotulagem nutricional e comportamento do consumidor de alimentos, especialmente considerando o cenário nacional. Isso se dá pela confirmação de que a presença de informações nutricionais completas no painel frontal das embalagens afeta positivamente e de forma mais consistente a percepção de saudabilidade do produto, se comparada ao uso de uma única forma de apresentação, levando a uma maior probabilidade de compra.

A seguir, apresenta-se a revisão de literatura acerca dos principais temas atinentes a este trabalho, seguida do detalhamento dos procedimentos metodológicos adotados, da análise dos dados e discussão dos resultados e, por fim, contribuições, limitações e implicações do estudo.

\section{Revisão de Literatura}

Três principais temas emergem para esta revisão de literatura - rotulagem nutricional, painel frontal e modelos de apresentação da informação - e serão discutidos a seguir.

\subsection{Rotulagem Nutricional}

A percepção dos consumidores sobre a saudabilidade dos alimentos pode ser considerada como um dos principais determinantes dos padrões de comportamento alimentar (Provencher, Polivy \& Herman, 2009). As informações no rótulo, especialmente as relacionadas a propriedades nutricionais, pode levar o consumidor a escolhas mais saudáveis (Cowburn \& Stockley, 2005; Drichoutis et al., 2007; Campos, Doxey \& Hammond, 2011). A causa natural dessa associação, entretanto, é bidirecional: a rotulagem nutricional pode 
promover dietas mais saudáveis, enquanto indivíduos com dietas mais saudáveis são mais propensos a procurar pelas informações nutricionais nos rótulos.

Em geral, os consumidores encontram utilidade nos rótulos nutricionais (ByrdBredbenner, Wong \& Cottee, 2000), embora alguns relatem um desejo por uma forma mais simples de apresentação das informações (Bitzios et al., 2011). Estudos aplicados nos Estados Unidos e na Austrália indicaram que os consumidores têm dificuldade de entender e interpretar a informação, devido à utilização de uma linguagem mais técnica por parte dos fabricantes (Cowburn \& Stockley, 2005; Campos, Doxey \& Hammond, 2011).

\subsection{Painel Frontal}

Com a ascensão dos supermercados ao posto de um dos mais importantes canais de distribuição de autosserviço, a embalagem ganha maior importância (Vyth et al., 2010). Na prática, a informação nutricional fornecida na embalagem pode ser a única fonte disponível ao consumidor no ponto de venda, assumindo o papel de vendedor silencioso (Gurgel, 2007).

Informações nutricionais no painel frontal das embalagens podem melhorar a precisão de julgamentos sobre a qualidade nutricional dos alimentos e bebidas (Roberto, 2012). O objetivo geral do painel frontal é fornecer aos consumidores informações mais úteis do que as tabelas nutricionais, além de ajudar a tomada de decisão dos compradores mais bem informados sobre os alimentos (Williams, 2005; Feunekes et al., 2008; Borgmeier \& Westenhoefer, 2009; Vyth et al., 2010; Miklavec et al., 2015).

Os compradores indicam utilizar as informações nutricionais dos rótulos para evitar certos ingredientes e consultar a quantidade de componentes específicos, especialmente gordura, calorias e açúcar (Balasubramanian \& Cole, 2002). Informações expostas no painel frontal das embalagens são percebidas como a solução perfeita para resumir todo o perfil nutricional e facilitar a compreensão (Azman \& Sahak, 2014).

Os rótulos, em particular os painéis frontais das embalagens, são considerados uma importante ferramenta para ajudar os compradores a fazerem escolhas mais saudáveis (Banterle, Cavaliere \& Ricci, 2013). A eficácia dos rótulos nutricionais continua a ser pesquisada, pois a rotulagem não pode ser totalmente bem-sucedida até que os consumidores sejam ensinados a usá-la, e orientações sobre informações nutricionais sejam incluídas na legislação (Higginson et al., 2002). A atenção às informações nutricionais no rótulo depende dos objetivos e das limitações de recurso que os consumidores enfrentam (Herpern \& Trijp, 2011). 
Mesmo que o fabricante prefira um rótulo simples, a lei pode exigir informações adicionais. No Brasil, a ANVISA é o órgão responsável por regulamentar as informações de rotulagem, orientando e exigindo dados considerados obrigatórios, bem como restringindo o que - e como - pode conter a embalagem dos produtos, a fim de contribuir com a organização da rotulagem nutricional e assegurar certa credibilidade aos consumidores em relação ao comunicado. O conjunto de itens obrigatórios na rotulagem de alimentos inclui valor energético, carboidratos, proteínas, gorduras saturadas e trans e sódio. $\mathrm{O}$ artigo $8^{\circ}$ da Lei $\mathrm{n}$. 9782/99 atribui à ANVISA a competência de regulamentar, controlar e fiscalizar os produtos e serviços que envolvam risco à saúde pública, dentre eles as embalagens para alimentos.

Além da ANVISA, o Código de Defesa do Consumidor (Lei 8.078/90, art. 6) também regulamenta a rotulagem, informando que todo produto deve trazer informações claras, precisas e em língua portuguesa, indicar prazo de validade, ingredientes, nome e endereço do fabricante dentre outros dados, como o número do Serviço de Inspeção Federal (ANVISA, 2005; Ferreira \& Lanfer-Marquez, 2007).

Seguindo as orientações específicas, indústrias e varejistas desenvolveram seus próprios sistemas de informação nutricional no painel frontal, utilizando várias metodologias, de forma a atingir diferentes perfis de consumo. Apresentar as informações de forma clara e consistente contribui com os consumidores na escolha do produto (Viswanathan \& Hastak, 2002), assim como contar com mensagens relativas a questões nutricionais pode facilitar o reconhecimento do alimento como uma opção saudável (Bolton, Cohen \& Bloom, 2006).

Pesquisas mostram que os consumidores frequentemente limitam sua busca por informações às contidas no painel frontal das embalagens, pois são mais facilmente acessadas (Kaltcheva, Patino \& Leventhal, 2013). As informações nutricionais na parte frontal da embalagem são consideradas uma das principais fontes de informação sobre a confiabilidade de um produto alimentar, seja pela credibilidade da empresa e do produto, seja pela confirmação das informações da tabela nutricional (Cannoosamy, Pugo-Gunsam \& Jeewon, 2014).

Para os consumidores em geral que não seguem uma dieta especial ou buscam algum nutriente específico, a atenção às informações nutricionais depende de estímulo. Esse direcionamento da atenção é amplamente determinado pela saliência de informações específicas dentro do campo visual (Yantis, 2000). O pressuposto é que a tarefa de busca é mais fácil se as informações se destacam, com uma saliência maior do que outros estímulos informados na embalagem. 
Segundo Bordenave (2002), a troca de mensagens via embalagem entre produtor e consumidor permite a formação de novos conceitos e significados que, caso o conjunto de informações contidas na embalagem se apresente de maneira clara, objetiva e ao alcance do entendimento do consumidor, origina reações positivas.

\subsection{Modelos de Apresentação da Informação}

Informações que criam expectativas (ou fazem o consumidor formar uma hipótese) sobre a contribuição nutricional do produto são conhecidas como claims ou alegações, que normalmente vêm em destaque, como um splash no painel frontal, e contêm uma informação comunicada de forma objetiva. Segundo a Comissão Europeia de Regulação (EC) citada por Zafar, Hashim e Halim (2016), claim é qualquer mensagem ou representação não obrigatória, incluindo representações pictóricas, gráficas ou simbólicas. Diante de tantas opções no ponto de venda, os claims ajudam o consumidor a economizar tempo e satisfazer a necessidade relacionada à saúde na escolha de alimentos (Spiller, 2011).

Essas alegações podem ser classificadas, ainda, como nutrition claims ou health claims. Os nutrition claims são alegações sobre o conteúdo nutricional que destacam características específicas de um alimento, normalmente sobre a presença ou nível de um nutriente (Williams, 2005), como "rico em fibras", "reduzido teor de gorduras", "zero açúcar”. Já health claims, de acordo com Zafar, Hashim e Halim (2016), é toda representação que afirma, sugere ou implica que há uma relação entre um alimento (ou um de seus ingredientes) e saúde (por exemplo, "reduz o colesterol" ou "previne a osteoporose"). No Brasil, a ANVISA não permite o uso de health claims no rótulo de embalagens de produtos, o que, porém, tanto no Brasil como em outros países, não tem prevenido a proliferação de um grande número de claims potencialmente confusos e enganosos que podem ser interpretados pelos consumidores como uma alegação implícita de saudabilidade (Williams, 2005). No mercado brasileiro, isso pode ser visto claramente: diversas empresas criam símbolos com nomenclaturas próprias relativas à composição do produto e comunicam como um diferencial exclusivo.

Os consumidores de produtos alimentares embalados se deparam com uma variedade de símbolos e ícones de nutrição nos painéis frontais das embalagens. Em geral, o objetivo desses modelos de apresentação da informação é ajudar os consumidores a fazerem escolhas mais saudáveis, destacando, de forma simples, informações do interesse do consumidor. Referente aos modelos de apresentação das informações nutricionais previamente estudados, 
Doxey e Hammond (2011) concluíram que os consumidores no contexto de uma dieta saudável expressaram desejo por informações nutricionais em forma de lista; uma impressão maior e mais legível das informações; uso de cor; utilização de termos mais simples; explicações de termos ou nutrientes; e uma aparência consistente entre os rótulos. Em outro estudo, Andrews, Burton e Kees (2011) revelaram que tanto a atitude quanto a intenção de compra para os produtos com qualquer dos sistemas de informação (modelos de apresentação da informação) foi significativamente mais alto do que em relação à embalagem sem um sistema de informação.

Assim, percebe-se que a literatura conta com estudos envolvendo modelos de apresentação da informação, suas características, eficácia e aceitação (Keller et al., 1997; Roe, Levy \& Derby, 1999; Herpen \& Trijp, 2011; Hodgkins et al., 2012; Roberto et al., 2012). Entre eles, definiram-se para este estudo aqueles mais comumente utilizados pelas indústrias no Brasil. Cada um dos modelos utiliza uma forma de apresentação das informações nutricionais, descrevendo-se a seguir e, posteriormente, sua apresentação visual é visualizada na Figura 1.

- Alegações nutricionais (nutrition claims): destacam características específicas de um alimento na forma textual, normalmente indicando presença ou nível de um nutriente, como "rico em fibras", "reduzido teor de gorduras", "zero açúcar" (Kaltcheva et al., 2013).

- GDA (Guideline Daily Amounts): indica a quantidade por porção e o percentual correspondente de valores diários recomendados (\%VD) de açúcares, gorduras totais, gorduras saturadas, sódio e valor energético (Feunekes et al., 2008).

- Sistema de nutriente específico (Nutrient-specific systems): conta somente com um símbolo destacando a presença ou a ausência de um nutriente específico do produto (Kaltcheva et al., 2013).

- Sistema de informação por grupo de alimento (Food group information systems): conta com uma informação textual junto a um símbolo referente ao nutriente que se deseja destacar a presença ou a ausência (Kaltcheva et al., 2013). 
Figura 1 - Exemplos dos Modelos de Apresentação da Informação Nutricional



Fonte: elaborado pelos autores com base na revisão de literatura.

Os modelos de apresentação da informação nutricional descritos foram utilizados no presente estudo. O capítulo a seguir detalha os procedimentos adotados.

\section{Método}

A fim de verificar a influência de diferentes formas de apresentação da informação nutricional na embalagem de alimentos na percepção de saudabilidade e na intenção de compra, foi realizada uma pesquisa quantitativa, do tipo survey online. Uma amostra de 399 adultos, residentes no Brasil, em diferentes estados e de diferentes faixas etárias, foi exposta a sete embalagens apresentadas de forma randômica, por meio do software Qualtrics.

Visto que o cereal matinal é uma categoria de alimentos utilizada em diversos estudos similares em relação à rotulagem nutricional (Lalor et al., 2010; Zafar, Hashim \& Halim, 2016), optou-se pelo uso do produto no presente estudo. No Brasil, o consumo per capita de cereais é um dos menores da América Latina, sendo, em 2016, de apenas 0,3 kg por pessoa, segundo o site Statista, mas com perspectiva de duplicar esse valor em 2020. Ainda que haja diferenças significativas de consumo entre os países, a ideia é verificar se as percepções no cenário brasileiro condizem com os resultados dos estudos realizados anteriormente sobre o 
tema nos Estados Unidos e na Europa. Por sua vez, a inclusão dos biscoitos se deu para contrapor e testar se há diferença de resultados em um produto não-saudável.

Segundo dados da Nielsen publicados pela Associação Brasileira das Indústrias de Biscoitos, Massas Alimentícias e Pães \& Bolos Industrializados, o brasileiro consumiu 8,700 kg de biscoito per capita no ano de 2017, sendo a maior parte de biscoitos recheados. Assim, no Brasil, o consumo de biscoitos supera significativamente o de cereais. A ideia de contrapor buscou identificar o produto adequado em uma pesquisa qualitativa com amostra de 12 adultos escolhidos por conveniência, perguntados sobre um produto que tenham o hábito de compra, embora saibam que não é saudável. Sete responderam "biscoito recheado". Definiuse, então, pela utilização de produtos da mesma marca, a fim de anular o efeito de marca.

Para verificar a percepção de saudabilidade e a intenção de compra em relação a cada um dos sistemas de informação, foram apresentadas sete diferentes embalagens (quatro do Nescau Cereal e três do biscoito Passatempo). As embalagens foram apresentadas de forma randômica, para tirar o ordenamento e não criar efeito de demanda. No sentido de ampliar o realismo da pesquisa, usou-se a embalagem real do produto, conforme encontrada atualmente no mercado (Bialkova \& Van Trijp, 2010), mantendo-se todos os elementos idênticos e variando apenas a forma de apresentação. As imagens foram manipuladas de forma a apresentarem total ou parcialmente as informações nutricionais originalmente expressas em suas embalagens reais.

A Figura 2 mostra cada um dos sistemas utilizados no painel frontal de cada um dos produtos. Além da embalagem contendo cada um dos sistemas ilustrados na Figura 2, cada produto também contou com a opções de painel frontal, com todos os sistemas, somando assim os sete cenários avaliados. As diferentes formas de apresentação da informação foram provenientes de modelos presentes no mercado brasileiro (GDA, nutrition claims, sistema de informação por grupo de alimento e cenário completo, com os três anteriores já explicados). 
Figura 2 - Modelos utilizados nas embalagens do estudo
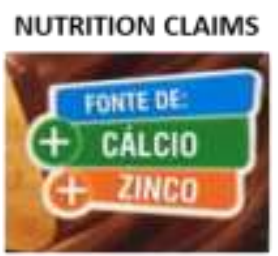

GDA

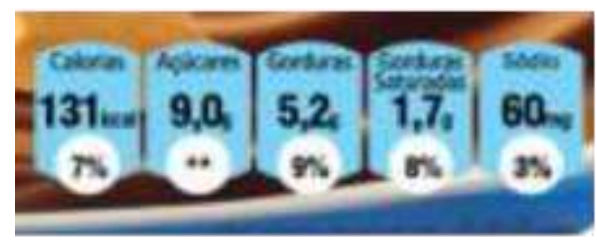

NUTRITION CLAIMS

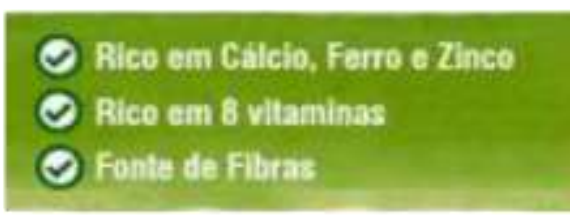

GDA

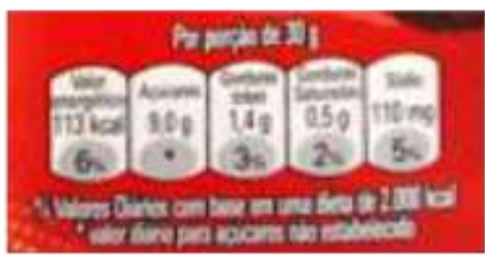

SISTEMA POR TIPO DE PRODUTO

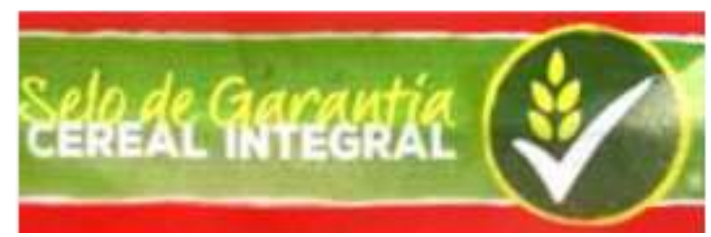

Fonte: Elaborado pelos autores.

Para que a posição dos modelos de informação no rótulo não tivesse interferência nas percepções sobre cada uma das diferentes formas de apresentação, no cereal matinal optou-se por aplicar as variações sempre no topo da embalagem. Essa abordagem está de acordo com orientações de Bialkova e Van Trijp (2010) e Bialkova, Grünert e Van Trijp (2013), cujos trabalhos concluíram que a atenção é capturada mais rapidamente quando a informação está posicionada na parte superior do rótulo. Isso é válido para o cereal matinal, em função do formato da embalagem. Já para o biscoito recheado, as variações foram aplicadas sempre na parte superior direita do painel. Por fim, para cada embalagem, as questões foram apresentadas seguindo a mesma ordem. Os participantes eram informados no início da pesquisa que seriam apresentadas sete embalagens e as respostas deveriam ser relativas a cada uma e, por isso, deveriam ser atentamente analisadas.

A primeira questão, para cada um dos sete cenários, era relativa à intenção de compra. Os participantes eram questionados sobre a probabilidade de compra do produto com a embalagem em questão em sua próxima ida ao supermercado. As respostas foram indicadas em uma escala likert de 5 pontos, variando de "muito improvável" a "muito provável", seguindo o padrão utilizado por outros estudos empíricos, a fim de mensurar a intenção de compra para diferentes configurações de produtos, como Burton e Pearse (2002), Giehl (2008) e Andrews, Burton e Kees (2011). A seguir, os respondentes indicavam a percepção de 
saudabilidade em relação ao produto, com a embalagem em questão, em uma escala de 5 pontos entre "nada saudável" e "extremamente saudável", seguindo modelo utilizado por Feunekes et al. (2008).

A validação do conteúdo do questionário foi realizada junto a experts da área, seguindo a orientação de Aaker, Kumar e Day (2004), sendo consultados dois doutores em marketing. $\mathrm{O}$ instrumento foi validado com base na revisão de literatura e sofreu adequações seguindo orientações dos experts. Foram realizados ajustes indicados como necessários para uma melhor compreensão das questões depois de realizada a tradução reversa por um expert em língua inglesa. Após a validação do instrumento de coleta, realizou-se pré-teste (Cooper \& Schindler, 2003), para identificar possíveis dificuldades e verificar se as questões estavam de fácil compreensão. O pré-teste foi aplicado pessoalmente em dez adultos, possibilitando a observação das reações e atitudes e identificação dos pontos que precisavam ser aperfeiçoados. A pesquisa foi divulgada por redes sociais, especialmente o Facebook, contemplando integrantes de todo o Brasil, de diferentes perfis demográficos.

A análise comparativa entre os efeitos das diferentes formas de apresentação da informação nutricional sobre a percepção de saudabilidade e a intenção de compra foi baseada na aplicação do Teste t pareado. Conforme Hair et al. (2009), o teste é adequado quando se buscam compreender as diferenças nas médias observadas em uma variável métrica (por exemplo, percepção de saudabilidade e intenção de compra) decorrentes de diferentes níveis ou tratamentos de um determinado fator (no caso, a forma de apresentação nutricional). A abordagem apresenta poucas limitações (comparação de no máximo dois grupos e uso de apenas uma variável independente de cada vez) que não interferem no objetivo deste estudo.

\section{Análise dos Resultados}

Os resultados deste trabalho são apresentados a seguir em três itens: 1) caracterização da amostra e perfil de consumo; 2) percepções de saudabilidade; e, 3) intenções de consumo.

\subsection{Caracterização da Amostra e Perfil de Consumo}

Os respondentes eram na maioria mulheres $(78,7 \%)$, a idade média de 35,94 anos, sendo 18 anos a idade do respondente mais novo e 57 anos a do mais velho. Em relação ao grau de escolaridade, $79,7 \%$ têm pelo menos o ensino superior completo (considerando os que responderam superior completo, especialização, mestrado ou doutorado). Apenas 1,8\% dos 
respondentes não possuem ensino médio completo; $8,8 \%$ somente o ensino médio completo e 9,8\% têm ensino superior incompleto. Em relação à renda familiar mensal, a maior parte dos respondentes possui superior a $\mathrm{R} \$ 3.520,01$ (72,3\%), sendo que destes, 31,8\% têm os ganhos familiares entre 4 e 10 salários mínimos. As faixas consideradas para o estudo seguiram as indicações do IBGE (2015). Dos 399 respondentes, 87,2\% declararam estar trabalhando.

Quando questionados sobre a frequência da consulta de informações nutricionais no momento da compra, 56,7\% indicaram que "sempre" ou "quase sempre" leem as informações nutricionais no momento da compra de um alimento, já 38,1\% indicaram ler somente no momento de preparo do alimento. Portanto, o momento da compra é o de maior consulta às informações nutricionais, assim como identificado nos estudos de Drichoutis, Lazaridis e Nayga (2005), Mannell et al. (2006); Drichoutis et al. (2007) e Giehl (2008).

Também foi investigada a frequência com que os compradores utilizam as informações nutricionais para decidir entre dois produtos no momento da compra. Segundo Higginson et al. (2002), o objetivo mais comum dos consumidores ao utilizarem a rotulagem nutricional é comparar produtos. O resultado indicou que 50,7\% dos respondentes fazem uso das informações nutricionais para escolher entre dois alimentos "sempre" ou "muitas vezes", e $21,1 \%$ "às vezes" comparam, de forma a decidir entre mais de um produto. Esses resultados corroboram com os obtidos nos estudos de Drichoutis, Lazaridis e Nayga (2005) e Mannell et al. (2006), nos quais os participantes já indicavam incorporar as informações nutricionais como importante fator de decisão na escolha de alimentos.

\subsection{Percepção de Saudabilidade}

Para analisar a percepção de saudabilidade, foi utilizada uma escala que contribuiu com estudos semelhantes (Feunekes et al., 2008; Kaltcheva, Patino \& Leventhal, 2013). Como forma de análise dos dados, primeiramente efetuou-se a análise das médias de percepção da saudabilidade entre cada uma das formas nutricionais apresentadas nas embalagens, por meio do teste t pareado. A Tabela 1 apresenta os resultados da percepção de saudabilidade em relação a cada embalagem utilizada do produto Cereal Matinal, e as diferenças foram significantes.

Em um contexto em que o consumidor se depara com uma embalagem com somente o GDA $(M=2,09 ; \mathrm{DP}=1,078)$ e outra com informações textuais além do GDA $(\mathrm{M}=2,56$; $\mathrm{DP}=1,146$ ), cuja adição torna a percepção de que o produto é mais saudável. Na comparação entre a embalagem somente com o GDA $(\mathrm{M}=2,09 ; \mathrm{DP}=1,078)$ e a com também o sistema de 
informação por grupo de produto $(\mathrm{M}=2,42 ; \mathrm{DP}=1,159)$, a embalagem com o selo de garantia aumenta a percepção de saudabilidade do produto. Já se compararmos a embalagem com o GDA acrescido de informações textuais com a embalagem contendo o sistema por grupo de produto $(\mathrm{M}=2,42 ; \mathrm{DP}=1,159)$, o melhor desempenho é da primeira $(\mathrm{M}=2,56 ; \mathrm{DP}=1,146)$. $\mathrm{O}$ sistema por grupo de produto só é visto como relacionado a um produto mais saudável $(\mathrm{M}=2,42 ; \mathrm{DP}=1,159)$ em comparação com embalagem com somente o GDA $(\mathrm{M}=2,09$; $\mathrm{DP}=1,078)$. Ou seja, quanto mais informação na embalagem, mais o consumidor percebe o produto como saudável. Assim, observa-se que a presença de mais informações (exposição com as três formas de apresentação utilizadas) impactou positivamente na percepção de saudabilidade do produto $(M=2,73 ; D P=1,261)$, sendo a embalagem percebida como de produto mais saudável.

Tabela 1 - Percepção de saudabilidade cereal matinal

\begin{tabular}{|c|c|c|c|c|c|}
\hline & Média & $\mathrm{N}$ & $\mathrm{DP}$ & teste t pareado & sig. \\
\hline GDA & 2,09 & 399 & 1,078 & \multirow{2}{*}{9,666} & \multirow{2}{*}{, 000} \\
\hline GDA_INFO & 2,56 & 399 & 1,146 & & \\
\hline GDA & 2,09 & 399 & 1,078 & \multirow{2}{*}{7,173} & \multirow{2}{*}{,000 } \\
\hline GDA_SC & 2,42 & 399 & 1,159 & & \\
\hline GDA & 2,09 & 399 & 1,078 & \multirow{2}{*}{11,342} & \multirow{2}{*}{,000 } \\
\hline CENÁRIO COMPLETO & 2,73 & 399 & 1,261 & & \\
\hline GDA_INFO & 2,56 & 399 & 1,146 & \multirow{2}{*}{3,271} & \multirow{2}{*}{,001 } \\
\hline GDA_SC & 2,42 & 399 & 1,159 & & \\
\hline GDA_INFO & 2,56 & 399 & 1,146 & \multirow{2}{*}{3,766} & \multirow{2}{*}{,000 } \\
\hline CENÁRIO COMPLETO & 2,73 & 399 & 1,261 & & \\
\hline GDA_SC & 2,42 & 399 & 1,159 & \multirow{2}{*}{6,550} & \multirow{2}{*}{, 000} \\
\hline CENÁRIO COMPLETO & 2,73 & 399 & 1,261 & & \\
\hline
\end{tabular}

Fonte: Coleta de dados.

$\mathrm{GDA}=$ painel frontal somente com o GDA; GDA_INFO= painel frontal com GDA e 'nutrition claims'; GDA_SC= painel frontal com GDA e sistema de informação por grupo de alimento.

$\mathrm{O}$ resultado para todos os testes $\mathrm{t}$ pareados indicou que, comparando a embalagem somente com o GDA e as embalagens com o GDA mais qualquer dos demais sistemas de informação, a embalagem com mais informação resultou em um aumento da percepção de saudabilidade do produto em todos os casos. A embalagem com somente o indicador GDA foi a com menor impacto na percepção de saudabilidade $(\mathrm{M}=2,09 ; \mathrm{DP}=1,078)$. Isso, provavelmente, em função de que as informações textuais tornam a compreensão mais clara 
em relação ao conteúdo do produto, já que os consumidores têm mais dificuldade em relação a informações numéricas e percentuais, como no GDA. Resultado semelhante foi encontrado no estudo de Bitzios et al. (2011).

O sistema por grupo de alimento, que funciona como um selo de garantia de qualidade, ou mesmo de saúde, não teve tanto impacto na percepção de saudabilidade em comparação a uma forma de apresentação que pode ser considerada mais simples, por conter somente informações textuais, como o caso dos nutrition claims, quando analisamos o cereal matinal, o que também se deu na análise em relação ao produto biscoito recheado. Para verificar a percepção de saudabilidade em relação às diferentes formas de apresentação da informação nutricional no rótulo do biscoito, foi feito novamente o teste $\mathrm{t}$ pareado, de forma a comparar cada uma das formas de apresentação de informação nutricional. Todas as diferenças foram significantes, conforme mostra a Tabela 2.

Tabela 2 - Percepção de saudabilidade biscoito recheado

\begin{tabular}{|c|c|c|c|c|c|}
\hline & Média & $\mathrm{N}$ & DP & teste $\mathrm{t}$ pareado & sig. \\
\hline GDA & 1,72 & 399 & ,909 & \multirow{2}{*}{4,524} & \multirow{2}{*}{, 000} \\
\hline INFO & 1,92 & 399 & 1,053 & & \\
\hline GDA & 1,72 & 399 & ,909 & \multirow{2}{*}{6,249} & \multirow{2}{*}{, 000} \\
\hline CENÁRIO COMPLETO & 2,01 & 399 & 1,133 & & \\
\hline INFO & 1,92 & 399 & 1,053 & \multirow{2}{*}{2,266} & \multirow{2}{*}{, 024} \\
\hline CENÁRIO COMPLETO & 2,01 & 399 & 1,133 & & \\
\hline
\end{tabular}

Fonte: Coleta de dados.

$\mathrm{GDA}=$ painel frontal somente com GDA; INFO= painel frontal somente com 'nutrition claims';

CENÁRIO COMPLETO = painel frontal contendo GDA e 'nutrition claims'.

Para o biscoito recheado, o resultado se repetiu: quanto mais informações na embalagem, maior a percepção de saudabilidade em relação ao produto. Isso pode ser concluído pois a embalagem com todas as formas de apresentação (cenário completo) foi a com maior média $(\mathrm{M}=2,01 ; \mathrm{DP}=1,133)$, tanto na comparação com o GDA $(\mathrm{M}=1,72$; $\mathrm{DP}=0,909)$ quanto com a embalagem contendo apenas informações textuais $(\mathrm{M}=1,92$; $\mathrm{DP}=1,053)$. Na comparação entre e embalagem com o GDA $(\mathrm{M}=1,72 ; \mathrm{DP}=0,909)$ e a contendo um splash com informações textuais $(\mathrm{M}=1,92 ; \mathrm{DP}=1,053)$, a segunda foi a percebida como mais saudável. 


\subsection{Intenção de Compra}

$\mathrm{Na}$ sequência, foi verificada a intenção de compra em relação a cada uma das embalagens. Para verificar a influência das diferentes formas de apresentação das informações nutricionais na intenção de compra, aplicou-se o teste $t$, comparando as diferenças de médias para a intenção de compra em relação às embalagens com cada uma das formas de apresentação da informação, bem como em relação ao cenário completo, com todos os formatos presentes.

Em primeiro lugar, efetuou-se a análise das médias registradas para a intenção de compra do produto Cereal Matinal (Tabela 3). Em seguida, foi feito teste t pareado, comparando as diferenças de intenção de compra entre cada uma das formas de apresentação de informação, do mais simples (GDA) ao mais completo dos sistemas (contexto completo). A média foi de 2,11 no mais simples ( $\mathrm{DP}=1,228)$, ou seja, a intenção de compra é menor no mais simples e maior no mais completo $(\mathrm{M}=2,60 ; \mathrm{DP}=1,382)$. A diferença é significativa entre os dois, portanto, pode-se dizer que, havendo mais informação, aumenta a intenção de compra. Esse resultado reforça o encontrado no estudo de Bialkova, Grunert e Van Trijp (2013) de que a atenção aumenta quando há uma combinação de sistemas de informação.

Tabela 3 - Probabilidade de compra do produto cereal matinal

\begin{tabular}{|c|c|c|c|c|c|}
\hline & Média & $\mathrm{N}$ & DP & teste t pareado & sig. \\
\hline GDA & 2,11 & 399 & 1,228 & & \\
\hline GDA_INFO & 2,47 & 399 & 1,309 & 7,788 &, 000 \\
\hline GDA & 2,11 & 399 & 1,228 & & \\
\hline GDA_SC & 2,28 & 399 & 1,278 & 3,790 &, 000 \\
\hline GDA & 2,11 & 399 & 1,228 & & \\
\hline CENÁRIO COMPLETO & 2,60 & 399 & 1,382 & 8,819 &, 000 \\
\hline GDA_INFO. & 2,47 & 399 & 1,309 & & \\
\hline GDA_SC. & 2,28 & 399 & 1,278 & 4,997 & ,000 \\
\hline GDA_INFO. & 2,47 & 399 & 1,309 & & \\
\hline CENÁRIO COMPLETO & 2,60 & 399 & 1,382 & 2,910 & ,004 \\
\hline GDA_SC & 2,28 & 399 & 1,278 & & \\
\hline CENÁRIO COMPLETO & 2,60 & 399 & 1,382 & 7,262 &, 000 \\
\hline
\end{tabular}

Fonte: Coleta de dados

$\mathrm{GDA}=$ painel frontal somente com o GDA; GDA_INFO= painel frontal com GDA e 'nutrition claims'; GDA_SC= painel frontal com GDA e sistema de informação por grupo de alimento. 
Em relação ao biscoito recheado, a Tabela 4 apresenta o resultado das análises. Da mesma forma que no cereal, foi feito um teste $\mathrm{t}$ pareado, comparando as diferenças de intenção de compra para cada uma das formas de apresentação nutricional na embalagem. Por ser classificado como não-saudável, não foi testado com o símbolo indicador resumido (informação por grupo de alimento), visto que o formato é restrito à indicação de saudabilidade de determinado produto.

Tabela 4 - Probabilidade de compra do produto biscoito recheado

\begin{tabular}{l|ccccc}
\hline & & & & teste t \\
& Média & $\mathrm{N}$ & DP & pareado & sig. \\
\hline GDA & 1,94 & 399 & 1,160 & 3,466 & \multirow{2}{*}{001} \\
INFO & 2,09 & 399 & 1,256 & & \\
\hline GDA & 1,94 & 399 & 1,160 & \multirow{2}{*}{0,189} &, 000 \\
CENÁRIO COMPLETO & 2,27 & 399 & 1,341 & & \\
\hline INFO & 2,09 & 399 & 1,256 & \multirow{2}{*}{4,974} &, 000 \\
CENÁRIO COMPLETO & 2,27 & 399 & 1,341 & & \\
\hline
\end{tabular}

Fonte: Coleta de dados.

$\mathrm{GDA}=$ painel frontal somente com GDA; INFO= painel frontal somente com 'nutrition claims';

CENÁRIO COMPLETO = painel frontal contendo GDA e 'nutrition claims'.

Também para o biscoito, a apresentação de um conjunto mais completo de informações aumenta a intenção de compra do produto $(\mathrm{M}=2,27 ; \mathrm{DP}=1,341)$, tanto em comparação com a embalagem com somente o GDA $(\mathrm{M}=1,94 ; \mathrm{DP}=1,160)$, como em relação à embalagem contendo somente informações textuais $(M=2,09 ; \mathrm{DP}=1,256)$. Ou seja, a intenção de compra de um produto não saudável aumenta conforme a embalagem conta com mais informação.

Já na exposição que compara a embalagem somente com o GDA (M=2,09; DP=1,256) ou somente nutrition claims $(\mathrm{M}=1,94 ; \mathrm{DP}=1,160)$, a informação textual se destaca com maior probabilidade de compra. Portanto, no caso em que a empresa tenha restrições de espaço no rótulo para a aplicação de mais de um sistema de informação, a utilização de nutrition claims é o mais indicado, visto que é o sistema com maior probabilidade de compra. Em resumo, a principal conclusão é que, quanto mais informações disponíveis, maior tende a ser a intenção de compra de um produto. 


\section{Discussão dos resultados}

A pesquisa envolvendo informação nutricional abarca conceitos dentro de três grandes temas: comportamento do consumidor de alimentos, marketing de produtos e rotulagem nutricional. A convergência dos temas tem sido citada como de importante relevância acadêmica, gerencial e social, motivando a realização deste estudo.

Nos Estados Unidos e na Europa, diversas são as maneiras utilizadas pelos fabricantes de alimentos de destacar informações nutricionais no painel frontal do rótulo de seus produtos, sendo que o consumidor já possui maior facilidade na leitura e compreensão das informações contidas nas embalagens, em função de um padrão utilizado pelas empresas que já familiarizou os consumidores com determinados modelos (Leathwood et al., 2007). No Brasil, ainda há espaço para maior conhecimento e aprofundamento acerca desses temas.

Assim, o objetivo deste trabalho foi investigar e compreender se: (a) diferentes formas de apresentação da informação nutricional no painel frontal das embalagens de alimentos interferem na percepção de saudabilidade e, (b) avaliar qual o modelo mais adequado de apresentar ou destacar informações no painel frontal para aumentar a probabilidade de compra. Ambos os objetivos foram atingidos, pois ficou comprovado que a inclusão de um sistema de informações mais completo no painel frontal de um alimento aumenta a percepção de saudabilidade.

De forma complementar, caso a empresa não queira ou não possa (por questões de espaço na embalagem) usar uma combinação de diferentes formas de apresentação da informação (cenário completo), o mais indicado para aumentar a percepção de saudabilidade do produto é a combinação do GDA com informações textuais, indicando seus diferenciais nutricionais (como rico em cálcio, contém 8 vitaminas, fonte de fibras etc.).

A forma de apresentar informações percebida como a que indica um alimento mais saudável foi a contendo os nutrition claims, muito utilizados no marketing das indústrias alimentícias no Brasil. Já em relação a quão saudável o produto aparenta ser, a única forma percebida como de maior saudabilidade foi a embalagem completa, que também inclui esse modo de comunicar os atributos e os diferenciais nutritivos. Esse resultado se repetiu tanto em relação aos cereais matinais, como quanto aos biscoitos recheados, além de serem similares aos encontrados em outros trabalhos (Fidling et al., 2018; Ikonen et al., 2019). Esses estudos confirmaram que a presença de informações nutricionais no painel frontal das embalagens, independentemente do tipo, aumenta a percepção de que o produto é saudável, sendo que, em 
geral, os nutrition claims e o sistema de informação por grupo de alimento são superiores ao GDA.

Os nutrition claims são informações objetivas e fáceis de compreender, que, por ressaltar qualidades nutricionais do alimento, impactam na percepção de saudabilidade de um produto. Ao contrário, o GDA, embora facilite o acesso à informação de parte da tabela nutricional, também destaca itens não desejados pelo consumidor (açúcar, sal, gorduras e calorias), podendo ser associado a indicar um produto não-saudável.

A intenção de compra foi testada para cada uma das formas de apresentação da informação em análise (nutrition claims, GDA, selo de garantia e rótulo completo), indicando que a maior probabilidade de compra se dá frente ao rótulo mais completo. As embalagens reunindo todos os modelos de apresentação testados foram apontadas como as que causam maior percepção de saudabilidade e resultam em maior intenção de compra. Logo, quanto mais informação, melhor. De um modo geral, a relação entre a apresentação de informações nutricionais e uma maior intenção de compra apresenta resultados conflitantes na literatura. Graham et al. (2016) e Fidling et al. (2018) não encontraram suporte para a hipótese de que a presença de informações no painel frontal ampliaria a probabilidade de compra. Já Ikonen et al. (2019) confirmou que tanto nutrition claims quanto o sistema de informação por tipo de produto (selo de garantia) são positivamente relacionados com a intenção de compra.

Um dado interessante é que na comparação entre o sistema de informação por grupo de alimento e o somente com informação textual (nutrition claims), o resultado indica que o produto com embalagem com o segundo tem maior probabilidade de compra do que o primeiro. Esses resultados sugerem um papel potencialmente favorável para qualquer informação no painel frontal, ou seja, no contexto dos estudos em questão, a intenção de compra aumentou quando qualquer dos ícones nutricionais estava presente no painel frontal da embalagem. Isso suporta a usabilidade potencial de informações no painel frontal de alimentos (desde que de uma forma não enganosa) na comunicação de informações úteis para os consumidores que precisam fazer avaliações e tomar decisões, conforme também apontado no estudo de Keller et al. (1997).

No caso em que a empresa não deseja ou não pode (por limitações de espaço) trabalhar com várias aplicações de informação nutricional em destaque no painel frontal, o indicado é utilizar os nutrition claims, modelo mais bem avaliado pelos consumidores quando comparados aos demais. Esse resultado vai ao encontro dos estudos de Williams (2005) e Feunekes et al. (2008), que recomendaram um formato mais simples de informação no painel 
frontal e sistemas mais detalhados no back (verso). Isso pode ajudar os consumidores a tomarem decisões mais rapidamente, como também fornecer informações mais detalhadas para aqueles que desejarem.

\subsection{Contribuições}

Como contribuições acadêmicas, este estudo colabora com as pesquisas na área de rotulagem nutricional e comportamento de compra do consumidor, especialmente com os estudos no cenário brasileiro, ainda escassos sobre o tema.

Em relação às contribuições gerenciais, os resultados do presente estudo representam contribuições para o mercado brasileiro, especialmente os departamentos de marketing e desenvolvimento de produto. Logo, traz insights e ratifica práticas de rotulagem nutricional que não apenas atraem a atenção do consumidor, como também aumentam a percepção de saudabilidade e a intenção de compra. Sua utilização na prática contribui, assim, para a promoção de uma imagem de produto saudável (desde que as informações no rótulo sejam coerentes com o que for destacado no painel frontal), bem como para o aumento das vendas.

Em um ambiente de autosserviço, onde as embalagens são as responsáveis por atrair, informar e conquistar o comprador, os resultados deste estudo contribuem com orientações que podem auxiliar as indústrias a encontrar e utilizar os melhores modelos para alcançar resultados positivos. Visto que o presente estudo mostrou que, exposta de forma adequada na embalagem, a informação nutricional gera um aumento nas vendas, esse resultado também é positivo para o varejista.

Este estudo tem ainda contribuições sociais, dado que os resultados apontam que as intenções de compra dos consumidores estão bastante relacionadas à quantidade de informações apontadas no rótulo dos alimentos, não necessariamente a saudabilidade. Assim, gestores públicos devem considerar verificar de que forma transformar o interesse do consumidor em informações detalhadas na real busca por critérios nas informações que, de fato, levem a uma decisão mais saudável de consumo, reduzindo na sociedade os riscos de obesidade e doenças relacionadas à alimentação.

\subsection{Limitações e Pesquisas Futuras}

Este estudo tem suas limitações, uma delas é a coleta de dados em ambientes de redes sociais, limitando o acesso a um perfil de consumidor com uso dessas redes e dentro do 
escopo da distribuição desta pesquisa. Deve-se considerar, ainda, questões de tempo de resposta e atenção do respondente em redes sociais. Outra limitação refere-se à forma como as embalagens foram apresentadas aos respondentes, sendo que o fato de o respondente ter visto outros tipos de embalagens dentro do contexto do estudo, ainda que randomizadas, pode ter influenciado a avaliação das embalagens subsequentes.

Referente ao filtro pelo qual os respondentes foram selecionados, também pode-se identificar como limitação deste estudo o fato de salvaguardas prévias sobre os alimentos pesquisados não terem sido consideradas. Assim, consumidores que não tenham gosto pelos alimentos pesquisados podem ter sido selecionados para participar do estudo e, eventualmente, responder de forma enviesada à questão sobre intenção de compra dos referidos produtos nas embalagens pesquisadas. Futuros estudos podem considerar diferentes formas de apresentação das embalagens, como por grupos, por exemplo, visando mitigar esses efeitos, além de formas de filtragem de respondentes mais estritas.

Ainda, considera-se como limitação do estudo a não inclusão de variáveis de controle, como intimidade com o produto ou a marca, assim como o tempo de uso dos produtos e os conhecimentos de pais sobre nutrição, além da possibilidade de as próprias crianças terem indicação médica para dieta ou restrição alimentar, o que poderia também influenciar a percepção acerca da saudabilidade dos alimentos. Portanto, sugere-se que futuros estudos contemplem essas avaliações.

Outros aspectos não pesquisados neste projeto e que poderão ser incluídos em estudos futuros referem-se a averiguar se a quantidade, e não o tipo de disposição de informações nutricionais, impactam a percepção de saudabilidade do consumidor. Poder-se-ia identificar, assim, se há limitações do consumidor em reconhecer quais informações são, de fato, fundamentais/determinantes, resultando em uma opção baseada na percepção de que "quanto mais informações, melhor".

Ainda como sugestão para pesquisas futuras, sugerem-se testar as situações de rotulagem nutricional em consumidores com restrições alimentares (como intolerância à lactose, doença celíaca e alergias), a fim de verificar se apresentam os mesmos resultados. Também seria interessante explorar os mesmos cenários, testando as percepções em relação a produtos saudáveis e não saudáveis, por meio da realização de um estudo comparativo dos impactos das informações do painel frontal em produtos extremamente saudáveis e não saudáveis. Questões envolvendo a posição do sistema no painel frontal, bem como diferenças de formatos e cores, também serão de grande valia se aplicados ao cenário brasileiro. 


\section{Referências}

Aaker, D.A., Kumar, V. \& Day, G.S. (2004). Pesquisa de Marketing. (2a ed.). São Paulo: Atlas.

ABIMAPI (2019). Associação Brasileira das Indústrias de Biscoitos, Massas Alimentícias e Pães \& Bolos. Recuperado a partir de https://www.abimapi.com.br/.

Andrews, J.C., Burton, S. \& Kees, J. (2011). Is simpler always better? Consumer evaluations of front-of-package nutrition symbols. Journal of Public \& Marketing, 30(2), 175-190.

Azman, N. \& Sahak, S. (2014). Nutritional Label and Consumer Buying Decision: A Preliminary Review. Procedia - Social and Behavioral Sciences, 490-498.

Balasubramanian, S.K. \& Cole, C. (2002). Consumers' search and use of nutrition information: The challenge and promise of the nutrition labeling and education act. Journal of Marketing, 66 (3), 112-127.

Banterle, A., Cavaliere, A. \& Ricci, E.C. (2013). Food labelled information: An empirical analysis of consumer preferences. International Journal on Food System Dynamics, 3 (2), 156-170.

Bialkova, S. \& VanTrijp, H. (2010). What determines consumer attention to nutrition labels? Food Quality and Preference, 21 (8), 1042-1051.

Bialkova, S., Grunert, K.G. \& Van Trijp, H. (2013). Standing out in the crowd: The effect of information clutter on consumer attention for front-of-pack nutrition labels. Food Policy, 41, 65-74.

Bitzios, M., Fraser, I. \& Haddock-Fraser, J. (2011). Functional ingredients and food choice: Results from a dual-mode study employing means-end-chain analysis and a choice experiment. Food Policy, 36 (5), 715-725.

Bolton, L.E., Cohen, J.B. \& Bloom, P.N. (2006). Does marketing products as remedies create "Get out of jail free cards"? Journal of Consumer Research, 33, 71-81.

Bordenave, J.E.D. (2002). Além dos meios e mensagens. (10a ed.). Petrópolis: Vozes.

Borgmeier, I. \& Westenhoefer, J. (2009). Impact of different food label formats on healthiness evaluation and food choice of consumers: a randomized-controlled study. $B M C$ Public Health, 9 (1), 1-12.

Burton, M. \& Pearse, D. (2002). Consumer attitudes towards genetic modification, functional foods, and microorganisms: A Choice modeling experiment for beer. AgBioForum, 5 (2), 51- 58.

Byrd-Bredbenner, C., Wong, A. \& Cottee, P. (2000). Consumer understanding of US and EU nutrition labels. British Food Journal, 102 (8), 615-629.

Campos, S., Doxey, J. \& Hammond, D. (2011). Nutrition labels on pre-packaged foods: a systematic review. Public Health Nutrition, 14 (8), 1496-1506.

Cannoosamy, K., Pugo-Gunsam, P. \& Jeewon, R. (2014). Consumer Knowledge and Attitudes toward Nutritional Labels. Journal of Nutrition Education and Behaviour, 46 (5), 334-340.

Cavaliere, A., Ricci, E.C., \& Banterle, A. (2015). Nutrition and health claims: Who is interested? An empirical analysis of consumer preferences in Italy. Food Quality and Preference, 41, 44-51.

Colby, S. E. et al. (2010). Nutrition marketing on food labels. Journal of Nutrition Education and Behavior, v. 42, n. 2, p. 92-98.

Cooper, D. R. \& Schindler, P.S. (2003). Métodos de Pesquisa em Administração. Porto Alegre: Bookman.

Cowburn, G. \& Stockley, L. (2005). Consumer understanding and use of nutrition labeling: a systematic review. Public Health Nutrition, Wallingford, 16 (2), 21-28. 
Drichoutis, A.C., Lazaridis, P. \& Nayga, R. Jr. (2005). Nutrition knowledge and consumer use of nutritional food labels. European Review of Agricultural Economics, 32 (1), 93-118.

Drichoutis, A.C., Lazaridis, P. \& Nayga, R. Jr. (2006). Consumer's use of nutritional labels: a review of research studies and issues. Academy of Marketing Science Review, 2006 (9), 122.

Drichoutis, A.C. et al. (2008). A theoretical and empirical investigation of nutrition label use. The European Journal of Health Economics. Eur. J. Health Econ., 9, 293-304.

Ferreira, A.B. \& Lanfer-Marquez, U.M. (2007). Legislação Brasileira referente à rotulagem nutricional de alimentos. Revista de Nutrição, 20 (1), 83-93.

Feunekes, G.I. J., Gortemaker, I. A., Willems, A.A., Lion, R \& Kommer, M. (2008) Front-ofpack nutrition labeling: Testing effectiveness of different nutrition labelling formats frontof-pack in four European countries. Appetite, 50, 57-70.

Fidling, M.G. et al. (2018). Comparing Five Front-of-Pack Nutrition Labes' Influence on Consumers' Perceptions and Purchase Intentions. Preventive Medicne, 106, 114-121, https://doi.org/10.1016/j.ypmed.2017.10.022.

Giehl, R. B. T. (2008). A importância das informações nutricionais nos rótulos de alimentos na intenção de compra do consumidor. (Dissertação de Mestrado). Faculdade de Administração e Negócios - Pontifícia Universidade Católica do Rio Grande do Sul, Porto Alegre, RS, Brasil.

Graham, D.J. et al. (2016). Impact of Explained versus Unexplained Front-of-Package Butrition Labels on Parent and Child Food Choices: a randomized trial. Public Health Nutrition. 20 (5), 774-785.

Gurgel, F.A. (2007). Administração da Embalagem. São Paulo: Thomson Learning. Hair J. et al. (2009). Análise Multivariada de Dados. (6a ed). Porto Alegre: Bookman. Herpen, E. \& Van Trijp, H. (2011). Front-of-pack nutrition labels. Their effect on attention and choices when consumers have varying goals and time constraints. Appetite, 57(1), 148160 .

Higginson, C., Rayner, M., Draper, S. \& Kirk, T. R. (2002). The Nutrition label - which information is looked at? Nutrition and Food Science, 32 (3), 92-99.

Ikonen, L., Sotgiu, F., Aydinli, A. \& Verlegh, P. (2019). Consumer effects of front-ofpackage nutrition labeling: an interdisciplinary meta-analysis. Journal of the Academy of Marketing Science, https://doi.org/10.1007/s11747-019-00663-9.

Kaltcheva, M.B., Kaltcheva, V., Patino, A. \& Leventhal, R. (2013). Front-of-package product labels: influences of varying nutritional food labels on parental decisions. Journal of Product \& Brand Management, 352-361.

Keller, S. B. et al. (1997). The effects of nutrition package claims, nutrition facts panels, and motivation to process nutrition information on consumer product evaluations. Journal of Public Policy \& Marketing, 256-269.

Lalor, F., Madden, C., McKenzie, K. \& Wall, P. G. (2001). Health claims on foodstuffs: A focus group study of consumer attitudes. Journal of Functional Foods, 3, 56-59.

Leathwood, P. D. et al. (2007). Consumer understanding of nutrition and health claims: sources of evidence. British Journal of Nutrition, 98 (3), 474-484.

Mannell, A. et al. (2006). French consumers' use of nutrition labels. Nutrition \& Food Science, 36 (3), 159-168.

Marchi, E., Caputo, V., Nayga R. Jr. \& Banterle, A. (2016). Time preferences and food choices: evidence from a choice experiment. Food Policy, 62, 99-109.

Miklavec, K.; Pravst, I.; Grunert, K.G.; Klopcic, M. \& Pohar, J. (2015). The influence of health claims and nutritional composition on consumer's yoghurt preferences. Food Quality and Preference, 43, 25-33. 
Provencher, V., Polivy, J., \& Herman, C. P. (2009). Perceived healthiness of food. If it's healthy, you can eat more! Appetite, 52 (2), 340-344.

Roberto, C.A., Bragg, M.A., Schwartz, M.B., Swamans, M.J., Musicus, A., Novak, N. \& Brownell, K.D. (2012). Facts up front versus traffic light food labels: a randomized controlled trial. American Journal of Preventive Medicine, 43 (2), 134-141.

Savoie, N., Barlow, K., Hervey, K., Binnie, M. \& Pasut, L. (2013). Consumer perceptions of front-of-package labelling systems and healthiness of foods. Canadian Journal of Public Health, 104 (5), 359-363.

Spiller, S. A. (2011). Opportunity cost consideration. Journal of Consumer Research, 38, 595-610.

Statista (2019). Breakfast Cereals. Recuperado a partir de https://www.statista.com/outlook/40090100/115/breakfast-cereals/brazil.

Viswanathan, M. \& Hastak, M. (2002). The role of summary information in facilitating consumers' comprehension of nutrition information. Journal of Public Policy \& Marketing, 21, (2), 305-318.

Vyth, E.L. et al. (2010). Actual use of a front-of-pack nutrition logo in the supermarket: consumer's motives in food choice. Public Health Nutrition, 13, p. 1882-1889.

Williams, P. (2005). Consumer understanding and use of health claims for foods. Nutrition Reviews, 63 (7), 256-264.

Yantis, S. (2000). Goal-directed and stimulus-driven determinants of attentional control. Attention and Performance, 18, 73-103.

Zafar, M.Z., Hashim, N.A., \& Halim, F. (2016) Consumer's perception toward health claims for healthy food selection. Journal of Scientific Research and Development, 3, 57-67. 